2. To: (Receiving Organization)

Distribution

5. Proj./Prog./Dept./Div.:

W-503, TWRS Privatization

Phase 1

8. Originator Renarks:

This document contains design requirements pertaining to 230

kV transmission line, substation, and $13.8 \mathrm{kV}$ distribution

power lines for delivering electric power to the TWRS Phase 1 Privatization Facilities.

11. Receiver Remarks: 11A. Design Baseline Document? [X] Yes [] No
3. From: (Originating Organization)

TWRS Functional Baseline

Integration

6. Design Authority/ Design Agent/Cog. Engr.:

Gurdhian Singh
4. Related EOT No.:

$N / A$

7. Purchase Order No.:

$N / A$

9. Equip./Component No.:

$N / A$

10. System/Bldg./Facility:

$200 \mathrm{E}$

12. Major Assm. Dwg. No.:

$N / A$

13. Permit/Permit Application No.: $N / A$

14. Required Response Date: $N / A$

\begin{tabular}{|c|c|c|c|c|c|c|c|c|c|c|}
\hline 15. & & & DATA & ANSMI & & & (F) & (G) & (H) & (I) \\
\hline $\begin{array}{l}\text { A } \\
\text { Item } \\
\text { No. }\end{array}$ & (B) Document/ & ving No. & $\begin{array}{l}\text { (C) } \\
\text { Sheot } \\
\text { No. }\end{array}$ & $\begin{array}{l}\text { (D) } \\
\text { Rev. } \\
\text { No. }\end{array}$ & $\begin{array}{l}\text { (E) Title or De } \\
\text { Tran }\end{array}$ & of Data & $\begin{array}{l}\text { Approval } \\
\text { Desig- } \\
\text { nator }\end{array}$ & $\begin{array}{l}\text { Reason } \\
\text { for } \\
\text { Trans- } \\
\text { mittal }\end{array}$ & $\begin{array}{l}\text { Origi- } \\
\text { nator } \\
\text { Dispo- } \\
\text { sition }\end{array}$ & $\begin{array}{l}\text { Receiv- } \\
\text { er } \\
\text { Dispo- } \\
\text { sition }\end{array}$ \\
\hline 1 & WHC-SD-WM- & $D-011$ & & 0 & $\begin{array}{l}\text { Design Req } \\
\text { Document f } \\
\text { Phase } 1 \mathrm{Pr} \\
\text { Electrical } \\
\text { System }\end{array}$ & $\begin{array}{l}\text { nents } \\
\text { oe } \\
\text { ization } \\
\text { er }\end{array}$ & ED & 1 & & \\
\hline 16. & & & & & KEY & & & & & \\
\hline App & zal Designator (F) & & Reas & or Tran & ittal (G) & & Dispo & ion $(\mathrm{H}) \&$ & & \\
\hline $\begin{array}{l}\text { E, S, } \\
\text { (see V } \\
\text { Sec. } 1\end{array}$ & $\begin{array}{l}\text { D or N/A } \\
\text { C-CM-3-5, } \\
\end{array}$ & $\begin{array}{l}\text { 1. Approv } \\
\text { 2. Releas } \\
\text { 3. Inform }\end{array}$ & $\begin{array}{l}\text { 4. R } \\
\text { 5. P } \\
\text { 6. D }\end{array}$ & $\begin{array}{l}\text { ow } \\
\text {-Revien } \\
\text { (Recei }\end{array}$ & Acknow. Required\} & $\begin{array}{l}\text { 1. Approved } \\
\text { 2. Approved } \\
\text { 3. Disapprov }\end{array}$ & $\begin{array}{l}\text { omment } \\
\text { v/comment }\end{array}$ & $\begin{array}{l}\text { 4. Reviey } \\
\text { 5. Revie } \\
\text { 6. Recei }\end{array}$ & $\begin{array}{l}\text { no/comr } \\
\text { wicomm } \\
\text { knowled }\end{array}$ & \\
\hline
\end{tabular}

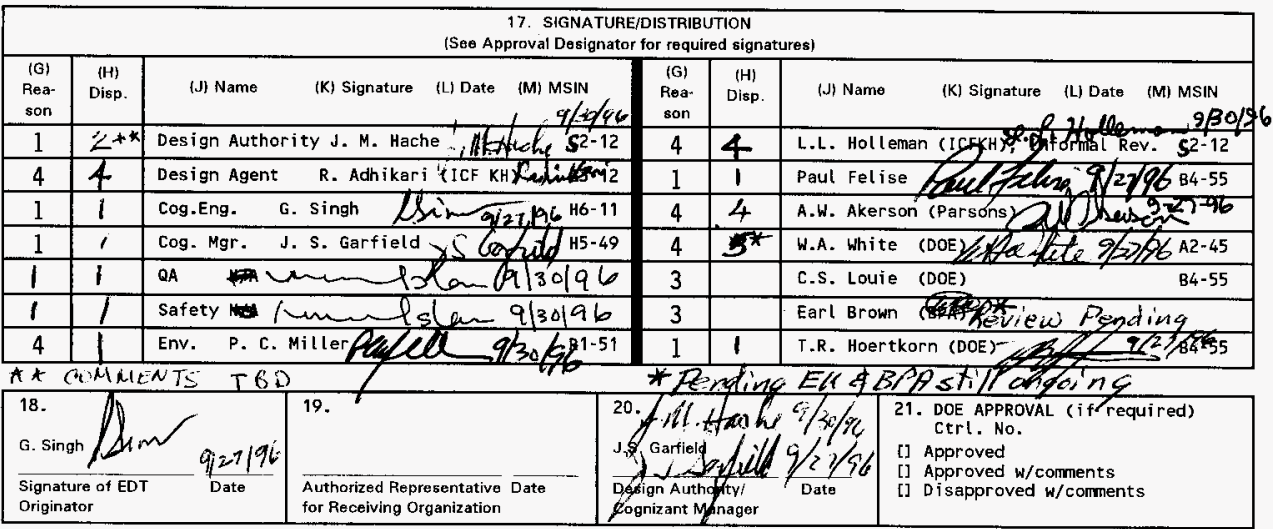




\title{
Design Requirements Document for the Phase I Privatization Electrical Power System
}

\author{
G. Singh
}

Westinghouse Hanford Company, Richland, WA 99352

A. W. Akerson

Parsons Infrastructure and Technology, Richland, WA 99352

R. Adhikari

ICF Kaiser Hanford Company, Richland, WA 99352

U.S. Department of Energy Contract DE-AC06-87RL10930

EDT/ECN: 608747

UC: 721

Org Code: 74F30

Charge Code: D627K

B\&R Code: EW3130010 Total Pages: 49

Key Words: electrical, privatization, TWRS, DRD, substation

Abstract: This document establishes design requirements for $230 \mathrm{kV}$ transmission, transformation (substation), and $13.8 \mathrm{kV}$ distribution systems needed to deliver electric power to the TWRS Phase 1 Privatized Facilities.

TRADEMARK DISCLAIMER. Reference herein to any specific commercial product, process, or service by trade name, trademark, manufacturer, or otherwise, does not necessarily constitute or imply its endorsement, recommendation, or favoring by the United States Government or any agency thereof or its contractors or subcontractors.

Printed in the United States of America. To obtain copies of this document, contact: WHC/BCS Document Control Services, P.O. Box 1970, Mailstop H6-08, Richland WA Fax (509) 376-4989.
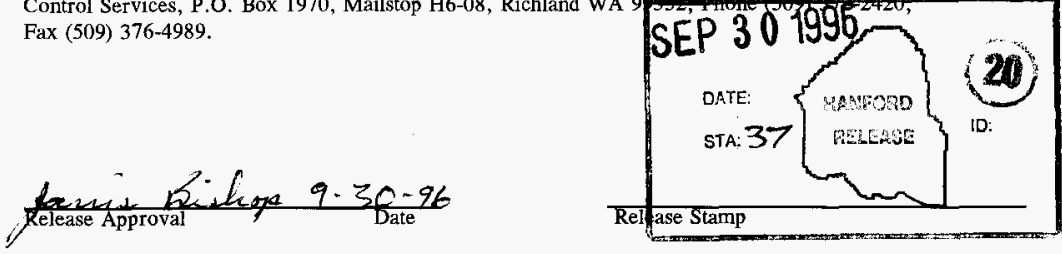

\section{Approved for Public Release}


WHC-SD-WM-DRD-011

Revision 0

\title{
DESIGN REQUIREMENTS DOCUMENT FOR THE PHASE I PRIVATIZATION ELECTRICAL POWER SYSTEM
}

September 1996

\author{
G. Singh \\ Westinghouse Hanford Company \\ Richland, Washington
}

A. W. Akerson

Parsons Infrastructure and Technology

Richland, Washington

R. Adhikari

ICF Kaiser Hanford Company

Richland, Washington

Prepared for

U.S. Department of Energy

Richland, Washington 
WHC-SD-WM-DRD-011

Revision 0

This page intentionally left blank. 
WHC-SD-WM-DRD-011

Revision 0

\section{CONTENTS}

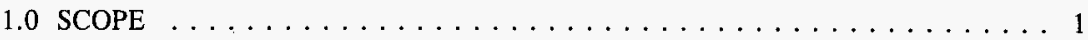

1.1 IDENTIFICATION $\ldots \ldots \ldots \ldots \ldots \ldots \ldots \ldots \ldots \ldots$

1.2 SYSTEM OVERVIEW $\ldots \ldots \ldots \ldots \ldots \ldots \ldots \ldots \ldots$

1.3 DOCUMENT OVERVIEW $\ldots \ldots \ldots \ldots \ldots \ldots \ldots \ldots \ldots$

2.0 APPLICABLE/COMPLIANCE DOCUMENTS $\ldots \ldots \ldots \ldots \ldots \ldots \ldots$

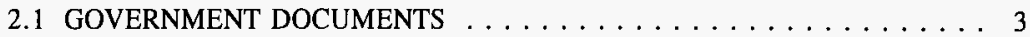

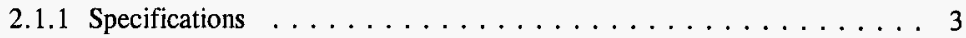

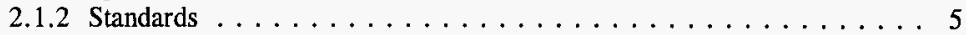

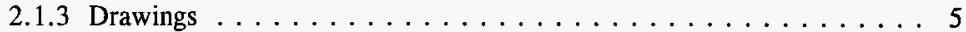

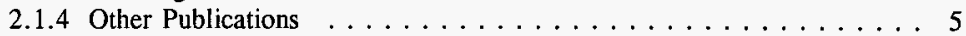

2.2 NON-GOVERNMENT DOCUMENTS $\ldots \ldots \ldots \ldots \ldots \ldots \ldots$

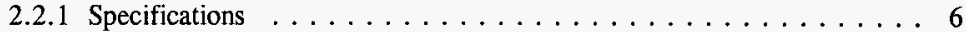

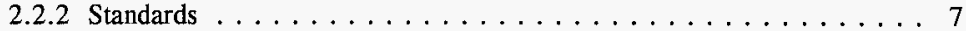

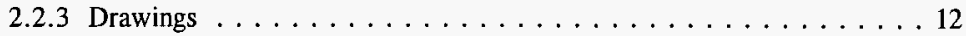

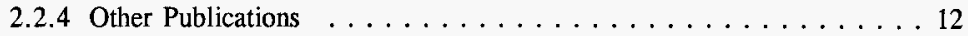

3.0 PROJECT FUNCTIONS AND REQUIREMENTS $\ldots \ldots \ldots \ldots \ldots \ldots$

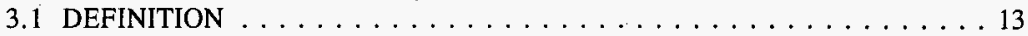

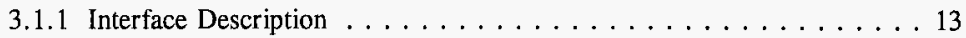

3.1 .2 Assumptions and Risks . . . . . . . . . . . . . . 14

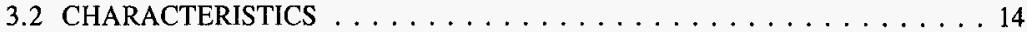

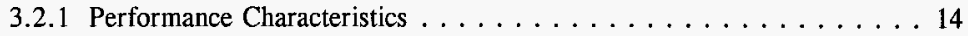

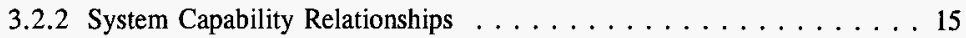

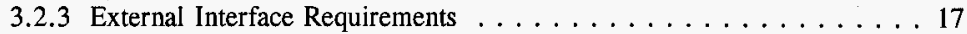

3.2 .4 Physical Characteristics $\ldots \ldots \ldots \ldots \ldots \ldots \ldots \ldots \ldots \ldots$

3.2 .5 Project Quality Factors $\ldots \ldots \ldots \ldots \ldots \ldots \ldots \ldots \ldots$

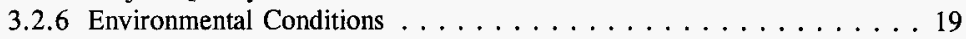

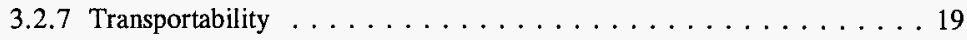

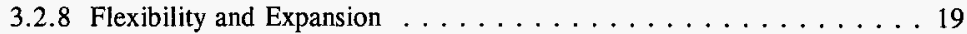

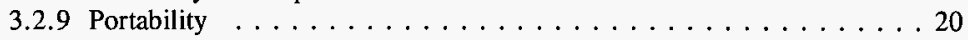

3.3 DESIGN AND CONSTRUCTION $\ldots \ldots \ldots \ldots \ldots \ldots \ldots \ldots \ldots \ldots$

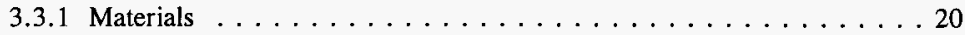

3.3.2 Electromagnetic Radiation . . . . . . . . . . . . . . 35

3.3.3 Nameplates and Product Markings . . . . . . . . . . . 36

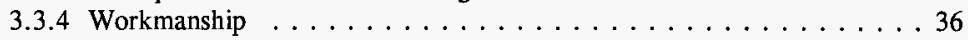

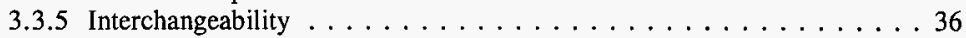

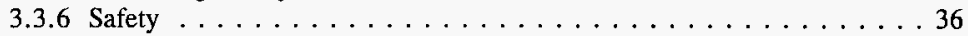


3.3.7 Human Engineering . . . . . . . . . . . . . . . . 36

3.3 .8 Nuclear control . . . . . . . . . . . . . . . . . 36

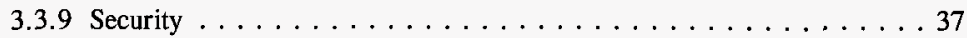

3.3.10 Government Furnished Property Usage . . . . . . . . . . . 37

3.3.11 Computer Resource Reserve Capacity . . . . . . . . . . . . . . 37

3.4 DOCUMENTATION $\ldots \ldots \ldots \ldots \ldots \ldots \ldots \ldots \ldots \ldots \ldots \ldots \ldots$

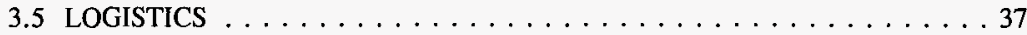

3.5 .1 Supply/Support $\ldots \ldots \ldots \ldots \ldots \ldots \ldots \ldots \ldots \ldots \ldots \ldots \ldots$

3.6 PERSONNEL AND TRAINING $\ldots \ldots \ldots \ldots \ldots \ldots \ldots \ldots \ldots \ldots$

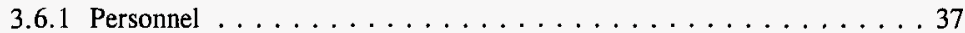

3.6 .2 Training . . . . . . . . . . . . . . . . 38

3.7 CHARACTERISTICS OF SUB-SYSTEM ELEMENTS $\ldots \ldots \ldots \ldots . \ldots 38$

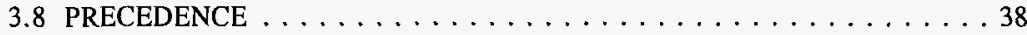

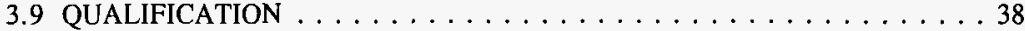

3.10 STANDARD SAMPLE $\ldots \ldots \ldots \ldots \ldots \ldots \ldots \ldots \ldots \ldots \ldots$

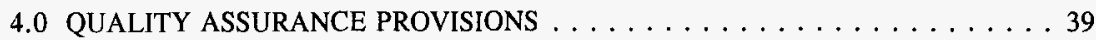

4.1 RESPONSIBILITY FOR INSPECTIONS $\ldots \ldots \ldots \ldots \ldots \ldots \ldots$

4.2 SPECIAL TESTS AND EXAMINATIONS $\ldots \ldots \ldots \ldots \ldots \ldots \ldots$

4.3 REQUIREMENTS CROSS REFERENCE . . . . . . . . . . . . . 39

5.0 PREPARATION FOR OPERATIONS $\ldots \ldots \ldots \ldots \ldots \ldots \ldots \ldots \ldots$

6.0 NOTES . . . . . . . . . . . . . . . . . . . 41

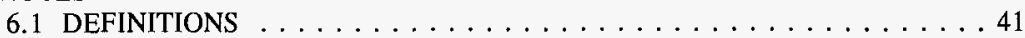

6.2 ABBREVIATIONS AND ACRONYMS $\ldots \ldots \ldots \ldots \ldots \ldots \ldots \ldots$

\section{FIGURE}

3-1. Phase I Privatization Facilities Electrical Power System Design

Requirements Hierarchy Diagram . . . . . . . . . . . . . . 21 
WHC-SD-WM-DRD-011

Revision 0

\section{DESIGN REQUIREMENTS DOCUMENT FOR THE PHASE I PRIVATIZATION ELECTRICAL POWER SYSTEM}

\subsection{SCOPE}

The TWRS Privatization Request for Proposals (DOE 1996), states that the Department of Energy will provide and maintain an electrical distribution system that is capable of delivering up to $20 \mathrm{MW}$ of electrical power, $13.8 \mathrm{kV}, 60$ hertz $(\mathrm{Hz})$, three-phase alternating current (AC), to the privatization contractor's site electrical distribution system. The primary function of the Phase I Privatization Facility Electrical Power Project is to provide the $20 \mathrm{MW}$ of electrical power, from a $13.8 \mathrm{kV}$ distribution system, to two Phase I privatization contractors for a total of $40 \mathrm{MW}$ of electrical power. This document describes the design requirements for the Phase I privatization electrical power system.

\subsection{IDENTIFICATION}

Program: Tank Waste Remediation System (TWRS) Low-Level Waste

Project: Electrical System Project

System: Electrical System for the Phase I Privatization Facilities.

\subsection{SYSTEM OVERVIEW}

The electrical system for the Phase I privatization facilities will support the TWRS mission by providing the electrical power to the Phase I privatized facilities performing the low-level waste immobilization activities. This system will receive power from the Department of Energy-Richland Operations (RL) A4-8 230 kiloVolts (kV) transmission system powered from Bonneville Power Administration (BPA) Ashe and Midway $230 \mathrm{kV}$ Substations. The existing RL $230 \mathrm{kV}$ transmission line will be modified and looped into the new $230 \mathrm{kV}$ substation bus. The new substation will be located in the vicinity of the privatized facilities, approximately $3.2 \mathrm{~km}(2 \mathrm{mi})$ south of the existing RL A4-8 $230 \mathrm{kV}$ transmission line. The substation will be capable of providing up to 40 megawatts (MW) of electrical power to support the Phase I privatization facilities and has the ability to accommodate future expansions. The substation will require at least two $230-13.8 \mathrm{kV}$ transformers, $13.8 \mathrm{kV}$ split bus switchgear, switchgear building, grounding transformers, instrument transformers, control and monitoring equipment, associated protection and isolation devices, lightning protection, yard lighting, cable and raceways, and infrastructure needed to provide desired availability and reliability. The power from the $13.8 \mathrm{kV}$ switchgear located in the switchgear building will be delivered at the privatization facilities 
site boundaries by providing a $13.8 \mathrm{kV}$ overhead distribution system. The $13.8 \mathrm{kV}$ distribution system inside the privatization facilities site boundaries is the responsibility of the privatization contractors.

\subsection{DOCUMENT OVERVIEW}

This document sets forth applicable government and non-government documents, functions and requirements, system characteristics including performance requirements, design and construction constraints, and quality assurance provisions applicable to the electrical system for the Phase I privatization facilities. These requirements will form a baseline for the conceptual design of the electrical system for the Phase I privatization facilities. Also, Figure 3-1 "Requirements Hierarchy Diagram" illustrates the electrical system components and requirements. 
WHC-SD-WM-DRD-011

Revision 0

\subsection{APPLICABLE/COMPLIANCE DOCUMENTS}

\subsection{GOVERNMENT DOCUMENTS}

The following documents, of the exact issue shown, form a part of this specification to the extent specified herein. In the event of conflict between the documents referenced herein and the contents of this specification, this specification shall be considered a superseding requirement. In the event that the document referenced herein has been revised, the most recent revision or issue shall be considered a superseding requirement.

\subsubsection{Specifications}

\subsubsection{Federal}

CFR, 1992, National Environmental Policy Act (NEPA): Implementing Procedures and Guidelines Revocation; Final Rule and Notice, 10 CFR 1021, Code of Federal Regulations, Office of the Federal Register, National Archives and Records Administration, Washington, D.C.

CFR, 1996, Oil Pollution Prevention, 40 CFR 112, Code of Federal Regulations, Office of the Federal Register, National Archives and Records Administration, Washington, D.C.

CFR, 1995a, Occupational Safety and Heath Administration, 29 CFR 1910, Code of Federal Regulations, Office of the Federal Register, National Archives and Records Administration, Washington, D.C.

CFR, 1995b, Occupational Safety and Heath Administration - Construction, 29 CFR 1926, Code of Federal Regulations, Office of the Federal Register, National Archives and Records Administration, Washington, D.C.

CFR, 1995c, Test Methods and Procedures, 40 CFR 61.93, Code of Federal Regulations, Office of the Federal Register, National Archives and Records Administration, Washington, D.C.

CFR, 1995d, Quality Assurance Requirements, 10 CFR 830.120, Code of Federal Regulations, Office of the Federal Register, National Archives and Records Administration, Washington, D.C.

2.1.1.2 Military. Not applicable. 
WHC-SD-WM-DRD-011

Revision 0

\subsubsection{Other Government Agency.}

BPA, 1980, Construction Data and Stringing Instructions for Midway-251 (A-2 Section) and 251-Ashe Tap (A-8 Section), 230 kV Single Circuit Transmission Line, Work Order 930-904, Bonneville Power Administration, Portland, Oregon.

DOE, 1989, General Design Criteria, DOE Order 6430.1A, U.S. Department of Energy, Washington, D.C.

DOE, 1992, Conduct of Operations, DOE Order 5480.19, U.S. Department of Energy, Washington, D.C.

DOE, 1993a, Environmental Protection, Safety and Health Protection, DOE Order 5480.4, U.S. Department of Energy, Washington, D.C.

DOE, 1993b, Fire Protection, DOE Order 5480.7, U.S. Department of Energy, Washington, D.C.

DOE, 1996, TWRS Privatization Request for Proposals, DOE-RP06-96RL-13308, January 1996, U.S. Department of Energy, Richland, Washington.

WAC, 1990, Washington Administrative Code, Safety Standards--Installing Electrical Wires and Equipment--Administrative Rules, WAC 296-46, State of Washington, Olympia, Washington.

WAC, 1994, Washington Administrative Code, Safety Standards for Electrical Workers, Chapter 296-45, State of Washington, Olympia, Washington.

WAC, 1995a, Washington Administrative Code, Public Water Supplies, Chapter 246-290, State of Washington, Olympia, Washington.

WAC, 1995b, Washington Administrative Code, Health Board and Division Department of Social Health Services, Chapter 248-96, State of Washington, Olympia, Washington. 


\section{WHC-SD-WM-DRD-011 \\ Revision 0}

\subsubsection{Standards}

2.1.2.1 Federal. Not applicable.

\subsubsection{Military}

ARMY, 1994, Human Engineering Design Criteria for Military System Equipment and Facilities, U. S. Department of the Army, MIL-STD-1472D, Springfield, Virginia.

2.1.2.3 Other Government Agencies. Not applicable.

\subsubsection{Drawings}

Not applicable.

\subsubsection{Other Publications}

\subsubsection{Federal.}

Not applicable.

\subsubsection{Military.}

Not applicable

\subsubsection{Other Government Agencies}

BPA, 1985, Description of FDAS - End-Use Load and Conservation Assessment Program, DOE/BPA/13795-4, October 1985, Bonneville Power Administration, Portland, Oregon.

\subsection{NON-GOVERNMENT DOCUMENTS}

The following documents, of the exact issue shown, form a part of this specification to the extent specified herein. In the event of conflict between the documents referenced herein and the contents of this specification, this specification shall be considered a superseding requirement. In the event that the document referenced herein has been revised, then the most recent revision or issue shall be considered a superseding requirement. 
WHC-SD-WM-DRD-011

Revision 0

\subsubsection{Specifications}

KEH, 1995a, Supervisory Control and Data Acquisition (SCADA) Computer System, Acquisition Plan \# WHC-95-353936, January 1995, ICF Kaiser Hanford Company, Richland, Washington.

KEH, 1995b, Hanford A/E Standards - Architectural/Civil (AC), KEH-MA-22, October, 1995, ICF Kaiser Hanford Company, Richland, Washington.

KEH, 1995c, Hanford A/E Standards - Electrical $(E)$, KEH-MA-25, October, 1995, ICF Kaiser Hanford Company, Richland, Washington.

KEH, 1995d, Underground Power Distribution, GE-UGPD-01, IFC Kaiser Hanford Company, Richland, Washington.

KEH, 1996, Design Loads for Facilities, GC-LOAD-01, ICF Kaiser Hanford Company, Richland, Washington.

PNNL, 1996, Climatological Data Summary 1995, with Historical Data, PNNL-11107, May 1996, Pacific Northwest National Laboratory, Richland, Washington.

PNNL, 1985, Development and Transfer of Energy Use Monitoring Technology at Pacific Northwest Laboratory, M. J. Fishbauger, Pacific Northwest Laboratory, Richland, Washington.

WHC, 1991, Microwave Transfer Trip Relay Project Final Definitive Report, WHC-SD-LL-FDR-001, Rev. 0, Westinghouse Hanford Company, Richland, Washington.

WHC, 1993, Electrical Utilities Distribution System Protective Relay Setting Guidelines, WHC-SD-LL-ES-034, Rev. 0A, Westinghouse Hanford Company, Richland, Washington.

WHC, 1996a, Environmental Compliance Manual, WHC-CM-7-5, Westinghouse Hanford Company, Richland, Washington.

WHC, 1996b, Farinon Microwave End of Life Cycle, WHC-SD-GN-ER-20007, Rev. 0, Westinghouse Hanford Company, Richland, Washington.

WHC, 1996c, Interface Control Document for Electricity, WHC-SD-WM-ICD-036, Rev, 0, Westinghouse Hanford Company, Richland, Washington. 


\section{WHC-SD-WM-DRD-011 \\ Revision 0}

WHC, 1996d, Engineering Study for the Phase I Privatization Facilities Electrical Power, WHC-SD-WM-ES-393, Rev. 0, Westinghouse Hanford Company, Richland, Washington.

Copies of specifications, standards, drawings, and publications required by suppliers in connection with specified procurement functions should be obtained from the contracting agency or as directed by the contracting agent.

\subsubsection{Standards}

AASHTO, 1993, Standard Method of Test for Specific Gravity and Absorption of Fine Aggregate, ASTM C128-88, American Association of State Highway and Transportation Officials, AASHTO T84, Washington, D.C.

ACI, 1995, Building Code Requirements for Structural Concrete, American Concrete Institute, ACI 318/rH, Detroit, Michigan.

AISC, 1989, Manual of Steel Construction, American Institute of Steel Construction Inc., 9th. Edition, Chicago, Illinois.

ANSI, 1983, Wet-Process Porcelain Insulators--Apparatus, Post Type, ANSI C29.9, New York, New York.

ANSI, 1984a, Wet-Process Porcelain Insulators-Low- and Medium-Voltage Pin Type, ANSI C29.5, New York, New York.

ANSI, 1984b, Wet-Process Porcelain Insulator--High-Voltage Pin Type, ANSI C29.6, New York, New York.

ANSI, 1985, Wet-Process Porcelain Insulators--Apparatus, Cap and Pin Type, ANSI C29.8, New York, New York.

ANSI, 1986, Wet-Process Porcelain Insulators--Spool Type, ANSI C29.3, New York, New York.

ANSI, 1988, Electrical Power Insulators-Test Methods, ANSI C29.1, New York, New York.

ANSI, 1989, Wet-Process Porcelain Insulators--Strain Type, ANSI C29.4, New York, New York.

ANSI, 1989, Wet-Process Porcelain Insulators--Indoor Apparatus Type, ANSI C29.10, New York, New York. 


\section{WHC-SD-WM-DRD-011}

Revision 0

ANSI, 1990, Extra-Strength PVC Plastic Utilities Duct for underground Installation, American Nation Standard Institute, ANSI/NEMA TC 8, New York, New York.

ANSI, 1995, American National Standard for Voltage Ratings for Electrical Power Systems and Equipment, American National Standard Institute, ANSI C84.1, New York, New York.

ASCE, 1988, Guide for Design of Steel Transmission Towers, American Society of Civil Engineers, ASCE 52, New York, New York.

ASCE, 1993, Design of Steel Transmission Pole Structures, American Society of Civil Engineers, ASCE 72, New York, New York.

ASCE, 1995, Minimum Design Loads for Buildings and Other Structures, American Society of Civil Engineers, ASCE 7, New York, New York.

ASHRAE, 1989, Energy Efficient Design of New Buildings Except Low-Rise Residential Buildings, American Society of Heating, Refrigeration, and Air-Conditioning Engineers, ASHRAE 90.1-1989 and 90.1-1993 addenda, Atlanta, Georgia.

FM, Loss Prevention Data Sheet on Transformers, Factory Mutual Engineering and Research, FM 5-4/14-8.

IEEE, 1972, Standard Requirements, Terminology, and Test Procedures for Neutral Grounding Devices, The Institute of Electrical and Electronics Engineers, Inc., 32-1972 Edition, New York, New York.

IEEE, 1983, Recommended Practice for Sizing Large Lead Storage Batteries for Generating Stations and Substations, The Institute of Electrical and Electronics Engineers, Inc., 485-1983 Edition, New York, New York.

IEEE, 1985, Guide for Protective Relay Applications to Power Transformers, The Institute of Electrical and Electronics Engineering, Inc., C37.91-1985 Edition, New York, New York.

IEEE, 1986a, Guide for Safety in AC Substation Grounding, The Institute of Electrical and Electronics Engineers, Inc., 80-1986 Edition, New York, New York.

IEEE, 1986b, Recommended Practice for Protection and Coordination for Industrial and Commercial Power Systems, The Institute of Electrical and Electronics Engineers, Inc., 242-1986 Edition, New York, New York. 


\section{WHC-SD-WM-DRD-011 \\ Revision 0}

IEEE, 1987, Recommended Practice for Installation Design and Installation of Large Lead Storage Batteries for Generating Stations and Substations, The Institute of Electrical and Electronics Engineers, Inc., 484-1987 Edition, New York, New York.

IEEE, 1988, Guide for Fence Safety Clearances in Electric-Supply Substations, The Institute of Electrical and Electronics Engineers, Inc., 1119-1988 Edition, New York, New York.

IEEE, 1989, Standard for Qualifying Permanent Connections Used in Substation Grounding, The Institute of Electrical and Electronics Engineers, Inc., 837-1989 Edition, New York, New York.

IEEE, 1990a, Recommended Practice for Power Systems Analysis, The Institute of Electrical and Electronics Engineers, Inc., 399-1990 Edition, New York, New York.

IEEE, 1990b, Recommended Practice for the Design of Reliable Industrial and Commercial Power Systems, The Institute of Electrical and Electronics Engineers, Inc., 493-1990 Edition, New York, New York.

IEEE, 1990c, Guide for the Design, Construction, and Operation of Safe and Reliable Substation Environmental Acceptance, The Institute of Electrical and Electronics Engineers, Inc., 1127-1990 Edition, New York, New York.

IEEE, 1990d, Trial-Use Design Guide for Wood Transmission Structures, The Institute of Electrical and Electronics Engineers, Inc., 751-1990 Edition, New York, New York.

IEEE, 1990e, Guide for Protective Grounding for Power Lines, The Institute of Electrical and Electronics Engineers, Inc., 1048-1990 Edition, New York, New York.

IEEE, 1991, Recommended Practice for Grounding of Industrial and Commercial Power Systems, The Institute of Electrical and Electronics Engineers, Inc., 142-1991 Edition, New York, New York.

IEEE, 1992, Electrical and Electronics Graphic and Logic Symbols and Reference Designation Standards Collection, The Institute of Electrical and Electronics Engineers, Inc., 1992 Edition, New York, New York.

IEEE, 1993a, National Electrical Safety Code, The Institute of Electrical and Electronics Engineers, Inc., C2-1993 Edition, New York, New York.

IEEE, 1993b, Electricity Metering Standards Collection, The Institute of Electrical and Electronics Engineers, Inc., C12-1993 Edition, New York, New York. 


\section{WHC-SD-WM-DRD-011 \\ Revision 0}

IEEE, 1993c, Recommended Practice for Electric Power Distribution for Industrial Power Systems, The Institute of Electrical and Electronics Engineers, Inc., 141-1993 Edition, New York, New York.

IEEE, 1993d, Standard for Metal-Oxide Surge Arresters for Alternating Current Power Circuits , The Institute of Electrical and Electronics Engineers, Inc., C62.11-1993 Edition, New York, New York.

IEEE, 1993e, Standard For Power Systems, Insulation Coordination, The Institute of Electrical and Electronics Engineers, Inc., 1313-1993 Edition, New York, New York.

IEEE, 1994, Guide for Containment and Control of Oil Spills in Substations, The Institute of Electrical and Electronics Engineers, Inc., 980-1994 edition, New York, New York.

IEEE, 1995a, Circuit Breakers, Switchgear, Substations, and Fuses Standards Collection, The Institute of Electrical and Electronics Engineers, Inc., C37-series 1995 Edition, New York, New York.

IEEE, 1995b, Distribution, Power, and Regulating Transformers Standards Collection, The Institute of Electrical and Electronics Engineers, Inc., C57-series 1995 Edition, New York, New York.

IEEE, 1995c, Pole Line Hardware Standards Collection, The Institute of Electrical and Electronics Engineers, Inc., C135-series 1995 Edition, New York, New York.

IEEE, 1995d, Surge Protection Standards Collection, The Institute of Electrical and Electronics Engineers, Inc., C62-1995 Edition, New York, New York.

IES, 1993, Lighting Handbook Application and Reference Volumes, Illuminating Engineering Society of North America, HB-93, New York, New York.

NEMA, 1988a, Cross-Linked Thermosetting Polyethylene Insulated Wire and Cable for the Transmission and Distribution of Electrical Energy, National Electrical Manufacturers Association, NEMA WC7-1988, Washington, D.C.

NEMA, 1988b, Ethylene-Polyethylene-Rubber-Insulated Wire and Cable for the Transmission and Distribution of Electrical Energy, National Electrical Manufacturers Association, NEMA WC8-1988, Washington, D.C.

NEMA, 1989, Polyvinyl-Chloride (PVC) Externally Coated Galvanized Rigid Steel Conduit and Intermediate Metal Conduit, National Electrical Manufacturers Association, NEMA RN1-1989, Washington, D.C. 


\section{WHC-SD-WM-DRD-011}

Revision 0

NEMA, 1990a, Electrical Plastic Tubing( ETP) and Conduit (EPC-40 and EPC-80), National Electrical Manufacturers Association, NEMA TC2-1990, Washington, D.C.

NEMA, 1990b, Extra Strength PVC Plastic Utilities Duct for Underground Applications, National Electrical Manufacturers Association, NEMA TC8-1990, Washington, D.C.

NEMA, 1991a, Enclosures for Electrical Equipment (1000V Maximum), National Electrical Manufacturers Association, NEMA 250-1991, Washington, D.C.

NEMA, 1991b, Metallic Cable Tray Systems, National Electrical Manufacturers Association, NEMA VE1-1991, Washington, D.C.

NEMA, 1992, Thermoplastic-Insulated Wire and Cable for the Transmission and Distribution of Electrical Energy, National Electrical Manufacturers Association, NEMA WC5-1992, Washington, D.C.

NEMA, 1993, Industrial Controls and Systems: Enclosures, National Electrical Manufacturers Association, NEMA ICS6-1993, Washington, D.C.

NFPA, 1993a, National Fire Alarm Code, National Fire Protection Association, Article 72-1993 Edition, Quincy, Massachusetts.

NFPA, 1993b, Lightning Protection Code, National Fire Protection Association, Article 780-1993 Edition, Quincy, Massachusetts.

NFPA, 1993c, Standard for Safeguarding Construction, Alteration, and Demolition Operations, National Fire Protection Association, Article 241-1993 Edition, Quincy, Massachusetts.

NFPA, 1994, Life Safety Code, National Fire Protection Association, Article 101-1994 Edition, Quincy, Massachusetts.

NFPA, 1995, Installation of Private Fire Service Mains and Their Appurtenances, National Fire Protection Association, NFPA 24, Quincy, Massachusetts.

NFPA, 1996, National Electrical Code, National Fire Protection Association, Article 701996 Edition, Quincy, Massachusetts.

UBC, 1994, Uniform Building Code, Volume 1 (Administrative, Fire \& Life Safety \& Field Inspection Provisions), Volume 2 (Structural Engineering Design Provisions), and Volume 3 (Materials, Testing \& Installation Standards), Whittier, California. 


\section{WHC-SD-WM-DRD-011 \\ Revision 0}

\subsubsection{Drawings}

Not applicable.

\subsubsection{Other Publications}

Not applicable.

Technical society and technical association specifications and standards are generally available for reference from libraries. They are also distributed among technical groups and federal agencies. 
WHC-SD-WM-DRD-011

Revision 0

\subsection{PROJECT FUNCTIONS AND REQUIREMENTS}

\subsection{DEFINITION}

The TWRS Privatization Request for Proposals (DOE 1996), states that the Department of Energy will provide and maintain an electrical distribution system that is capable of delivering up to $20 \mathrm{MW}$ of electrical power, $13.8 \mathrm{kV}, 60 \mathrm{hertz}(\mathrm{Hz})$, three-phase alternating current $(\mathrm{AC})$, to the privatization contractor's site electrical distribution system. The primary function of the Phase I Privatization Facility Electrical Power Project is to provide the $20 \mathrm{MW}$ of electrical power, from a $13.8 \mathrm{kV}$ distribution system, to two Phase I privatization contractors for a total of $40 \mathrm{MW}$ of electrical power. The Engineering Study for the Phase I Privatization Facilities Electrical Power (WHC 1996d) recommends a preferred alternative to deliver the required electrical power to the privatization contractors. The preferred alternative is to construct a new $230-13.8 \mathrm{kV}$ substation and associated $13.8 \mathrm{kV}$ distribution and $230 \mathrm{kV}$ transmission infrastructure system. The Engineering Study recommends that the RL $230 \mathrm{kV}$ transmission system be modified to add a new $230-13.8 \mathrm{kV}$ substation between the A-8 substation (251-W, approximately $6.4 \mathrm{~km} \mathrm{[4} \mathrm{mi]} \mathrm{northwest} \mathrm{of} \mathrm{the}$ 200 East Area) and the A-22 switchstation (Ashe Tap, approximately $8 \mathrm{~km}[5 \mathrm{mi}]$ to the eastnortheast of the 200 East Area). The Engineering Study also recommends that the electrical utility system service to the privatization contractors be operated with an availability as close to 100 percent as economically achievable so as to avoid curtailed operations, during planned maintenance of electrical utility equipment. The new substation will require two 230-13.8 $\mathrm{kV}$ transformers and an associated $230 \mathrm{kV}$ and $13.8 \mathrm{kV}$ infrastructure to support the desired availability and reliability of the electrical service to the Phase I privatization contractors.

\subsubsection{Interface Description}

The structures, systems, and components necessary to distribute, monitor, and control the availability of electrical power to the Phase I privatization contractor's site perimeter are considered to be the subject to this DRD. The electrical power system will consist of equipment necessary to transmit, transform voltages from $230 \mathrm{kV}$ to $13.8 \mathrm{kV}$, and distribute electrical power. The electrical power system shall also have the capability of providing up to $40 \mathrm{MW}$ of electrical power to support the Phase I privatization facilities and shall have the ability to expand to accommodate future loads. The Hanford Site utilities shall have operational and administrative control of the subject electrical transmission, substation, and distribution systems up to the privatization contractor's site perimeter. 
WHC-SD-WM-DRD-011

Revision 0

\subsubsection{Assumptions and Risks}

3.1.2.1 Privatization Contractor Electrical Load Profiles. The process and type of waste immobilization system to be used by the privatization contractors are unknown at this time. Therefore, a definitive electrical load profile for the privatization facilities will not be known until the electrical data are received from the privatization contractor. Although definitive load data will be provided by the privatization contractor after the contract award (DOE 1996), it is assumed that the privatization facilities will require $40 \mathrm{MW}$ by 2003 . Bonneville Power Administration studies (WHC 1996d, Appendix C) indicate that up to $60 \mathrm{MW}$ of electrical power can be delivered by the RL $230 \mathrm{kV}$ transmission system, therefore a design margin of 50 percent is provided by the Engineering Study's preferred alternative (WHC 1996d).

3.1.2.2 Privatization Contractor Electric Reliability/Availability Requirements. The reliability and availability requirements of the privatization contractors are unknown at this time. Although definitive reliability and availability requirements will be provided by the privatization contractor after the contract award (DOE 1996), it is assumed that the typical Hanford Site $230 \mathrm{kV}$ transmission substation configuration, used at each of the five existing RL $230 \mathrm{kV}$ substations, will be adequate to provide the privatization contractor's reliability and availability requirements.

3.1.2.3 Bonneville Power Administration Voltage Regulation. Voltage regulation problems at the new substation are indicated in preliminary BPA study (WHC 1996d). If the final BPA study confirms the same problem, a $13.8 \mathrm{kV}$ voltage regulation device shall be provided at the new $230 \mathrm{kV}$ substation to ensure voltage service requirements are satisfied (WHC 1996d, Appendix C).

\subsection{CHARACTERISTICS}

\subsubsection{Performance Characteristics}

3.2.1.1 $230 \mathrm{kV}$ Transmission System. The transmission system shall transmit electrical power from the RL $230 \mathrm{kV}$ transmission system to the new substation. The RL $230 \mathrm{kV}$ transmission system shall be modified to add a new $230-13.8 \mathrm{kV}$ substation between the A-8 substation (251-W, approximately $6.4 \mathrm{~km} \mathrm{[4} \mathrm{mi]} \mathrm{northwest} \mathrm{of} \mathrm{the} 200$ East Area) and the A-22 switchstation (Ashe Tap, approximately $8 \mathrm{~km}$ [5 mile] to the east-northeast of the 200 East Area). This section of the RL $230 \mathrm{kV}$ transmission system is referred to as the A-8 to A-22 line or the A-8 to Ashe Tap line. The new $230 \mathrm{kV}$ substation would be located in the 200 Areas, close to the privatization facilities. The new $230 \mathrm{kV}$ transmission lines would be tapped into the existing RL $230 \mathrm{kV}$ transmission system and routed approximately $3.2 \mathrm{~km}$ ( 2 mile) to the new substation. The performance, capabilities, availability, and reliability of the existing RL 230-kV transmission system shall not be degraded as a result of extending the system into the 200 Areas and new $230-\mathrm{kV} / 13.8-\mathrm{kV}$ substation. 
The transmission system shall be adequately grounded, protected against lightning and switching transients, electrical faults, and overloads. Physical protection shall also be provided at all railroad and vehicular crossings. Transmission line impedance shall not adversely impact the voltage regulation of the RL $230 \mathrm{kV}$ transmission system. A single point of failure of one of the two transmission lines to the new substation, shall not cause the second transmission line to fail, thereby resulting in a complete substation outage (blackout).

3.2.1.2 Transformation (Substation) System. The substation system shall transform the $230 \mathrm{kV}$ transmission system to a $13.8 \mathrm{kV}$ distribution system. The new electrical substation system shall have a goal of 100 percent availability so as to avoid curtailed operations to the privatization contractor, during planned maintenance of electrical utility equipment. In the event of a single bus/transformer outage, the remaining transformer and associated distribution system will provide the power requirements of the two privatization facilities. In the unlikely event that the entire substation is out of service, the privatization facilities will be required to provide their own emergency and backup power. The substation system shall consider further expansion due to future (TBD) loads. The substation system shall also be compatible with the existing 200 Areas electrical distribution system to allow interconnection of the two distribution systems.

Substation electrical loads shall not adversely impact the voltage regulation of the RL $230 \mathrm{kV}$ transmission system. If the voltage regulation is adversely impacted, the regulating equipment, such as load tap changing transformers; capacitors, or voltage regulators shall be used to correct the voltage regulation to acceptable limits. A single point failure of a substation component, shall not result in a complete substation outage.

3.2.1.3 13.8 kV Distribution System. The electrical distribution system shall be reliable, flexible and provide two distribution lines to each privatization contractor. Each distribution line shall have the capability to deliver electrical power, at $13.8 \mathrm{kV}$ nominal line voltage, to meet needs of each privatization contractor facility. The distribution lines to the privatization contractor service point shall be dedicated express feeders, or be provided with sectionalizing features to maintain reliable service to the privatization contractor. The distribution system shall be capable of meeting voltage regulation requirements of ANSI C84.1 (ANSI 1995).

\subsubsection{System Capability Relationships}

\subsubsection{Definition of Operating Modes}

3.2.2.1.1 Transmission System Normal Configuration. Normal configuration will consist of two separate services (transmission lines), radially supplied from separate sources (i.e., different remote substations), having sectionalizing features. Of the two transmission lines providing power to the substation, one will originate from the 251-W (A8) substation. The second transmission line will originate from the Ashe-Tap (switchstation A-22), which is supplied from the 151-KW (A7) substation and the Ashe substation. 
3.2.2.1.2 Transmission System Single Line Outage Configuration. Single line outage configuration will consist of one transmission line that is out of service, as a result of a planned or an unplanned outage. The remaining transmission line (second service) shall provide the sole source of electrical power, from the transmission system, to the substation.

3.2.2.1.3 Transmission System Dual Line Outage Configuration. Dual line outage configuration will consist of both transmission lines, that are out of service, as a result of a planned or an unplanned outage. This configuration would result in an electrical blackout of the privatization facilities. In the event of an electrical blackout, the privatization contractor facilities shall provide their own emergency, standby and alternate (backup) power systems.

3.2.2.1.4 $230 \mathrm{kV}$ Substation Normal Configuration. The $230 \mathrm{kV}$ Substation normal configuration will consist of two separate $230-13.8 \mathrm{kV}$ transformers providing service to two $13.8 \mathrm{kV}$ switchgear buses. The $13.8 \mathrm{kV}$ buses shall be separated by an open bus-tie breaker and all feeder breakers providing power to the privatization contractors shall remain in service. Substation support services, such as protective relaying controls, monitoring and metering equipment, etc. shall also remain in operation.

3.2.2.1.5 $230 \mathrm{kV}$ Substation Bus-Transformer Outage. The $230 \mathrm{kV}$ substation bustransformer outage configuration will consist of one $230 \mathrm{kV}$ bus or transformer that is out of service as a result of a planned or unplanned outage. The remaining bus and transformer shall be the sole source of electrical power to the $13.8 \mathrm{kV}$ switchgear buses.

3.2.2.1.6 $230 \mathrm{kV}$ Substation Total Bus-Transformer Outage. The $230 \mathrm{kV}$ substation total bus-transformer outage configuration will consist of both $230 \mathrm{kV}$ buses or both transformers, or a combination thereof, which results in both services being (transformers) out of service. This configuration would result in an electrical blackout of the privatization facilities. In the event of an electrical blackout, the privatization contractor facilities shall provide their own emergency and backup power.

3.2.2.1.7 13.8 kV Switchgear Bus Outage. The $13.8 \mathrm{kV}$ switchgear bus outage configuration will consist of one $13.8 \mathrm{kV}$ switchgear bus out of service as a result of a planned or unplanned outage. The remaining $13.8 \mathrm{kV}$ switchgear bus and feeder shall supply the load.

3.2.2.1.8 $13.8 \mathrm{kV}$ Switchgear Bus Total Outage. The $13.8 \mathrm{kV}$ switchgear bus total outage configuration will consist of both $13.8 \mathrm{kV}$ switchgear buses out of service as a result of a planned or unplanned outage. This configuration would result in an electrical blackout of the privatization facilities. In the event of an electrical blackout, the privatization contractor facilities shall provide their own emergency and backup power.

3.2.2.1.9 Distribution System Single Line Outage. Distribution system single-line outage configuration will consist of one distribution line (service) that is out of service and not providing power to a privatization contractor as a result of a planned or an unplanned 
outage. Electric power from a second distribution line shall be available to the privatization contractor.

3.2.2.1.10 Distribution System Dual Line Outage. Distribution system dual-line outage configuration consists of two distribution lines (service) that are out of service and are not providing power to a privatization contractor as a result of a planned or unplanned outage. This configuration would result in an electrical blackout of the privatization facilities. In the event of an electrical blackout, the privatization contractor facilities shall provide their own emergency and backup power.

\subsubsection{External Interface Requirements}

The Phase I Privatization Facilities Electrical Power Project has several external interfaces with existing systems and several external interfaces with ongoing Projects and Programs. In addition to the interface requirements described in the Interface Control Document for Electricity (WHC 1996c) the following paragraphs provide more detail on several external interface requirements.

3.2.3.1 Electrical Utility Systems. Modifications to the Hanford Site $230 \mathrm{kV}$ transmission system, substation configuration, and $13.8 \mathrm{kV}$ distribution systems shall be coordinated with the Hanford Site Electrical Utilities group. Also, $230 \mathrm{kV}$ transmission system modifications must meet existing BPA power grid regulations and requirements.

3.2.3.2 Water Utility Systems. Water shall be secured from the Hanford Site Water Utilities group. Water may be required in substations to provide domestic needs in the switchhouse if the substation is to be fully attended or partly attended or if a water or fog type fire protection system is used.

3.2.3.3 Sewer Utility Systems. If a water utility system is provided for domestic needs then a sewage disposal system shall be secured from the Hanford Site Sewer Utilities group. No untreated sewage shall be discharged onto the surface of the ground or into any surface stream. Where sanitary sewers are available the connection shall be made thereto, otherwise, septic tank treatment with underground effluent disposal shall be provided.

3.2.3.4 Bonneville Power Administration. Modifications to the Hanford Site $230 \mathrm{kV}$ transmission system shall be coordinated with the BPA. As stated in Section 3.1.2.3, voltage regulation at BPA's Ashe substation will be impacted by the additional privatization facilities electrical load. Efforts to minimize the voltage regulation impact shall be coordinated. The $230 \mathrm{kV}$ transmission line protective relaying system telecommunication circuits, located at the BPA Ashe substation, shall be re-directed to communicate with the new $230 \mathrm{kV}$ substation (currently the BPA telecommunication circuits communicate to the 251-W substation at Hanford). Protective relay coordination shall be coordinated with BPA to ensure proper selectivity is achieved. 
3.2.3.5 Telecommunications Systems. Telecommunication services shall be secured from the hanford Site Telecommunications group. Switch house telecommunication services will include circuits for voice communications, data collection, supervisory control of components, etc. Redundant telecommunication circuits will also be required for the $230 \mathrm{kV}$ transmission line protective relaying system and SCADA. The $230 \mathrm{kV}$ transmission line protective relaying system shall interface with the protective relaying system, located at the BPA Ashe substation. The telecommunication system supporting the $230 \mathrm{kV}$ transmission and substation must be coordinated with the ongoing study Farinon Microwave End of Life Cycle (WHC 1996b).

3.2.3.6 Privatization Contractor. The electrical service/interface point conditions shall be coordinated with the Hanford Site Electrical Utilities group. Electrical service/interface point conditions include revenue metering details, reliability and availability requirements, establishing points of contact, and developing an interface agreement with the Hanford Site Electrical Utilities group.

\subsubsection{Physical Characteristics}

The electrical transmission substation and distribution systems components shall be suitable for high voltage environmental conditions, climatic conditions, and the stress of daily operation. Other design considerations should include accessibility, maintainability, calibration and testing.

\subsubsection{Project Quality Factors}

3.2.5.1 Reliability. Detailed reliability requirements have not been developed because the reliability requirements for the privatization contractor are unknown at this time. Therefore, the reliability requirements have been identified and described in general terms.

3.2.5.1.1 Substation System Reliability. Two separate services, supplied from a loop-type transmission system shall supply power to the substation system.

3.2.5.1.2 Privatization Contractor Electrical Service. Two separate services, supplied from the substation system, shall supply the privatization contractor electrical service point.

3.2.5.2 Maintainability. The systems, subsystems, and components required as part of the Phase I Privatization Facilities Electrical Power Project shall be designed to incorporate the objective of efficient maintainability. The surveillance, testing, and maintenance of a system and its restoration to operational effectiveness shall be achieved at minimum cost with a minimum level of support services. 


\section{WHC-SD-WM-DRD-011 \\ Revision 0}

3.2.5.2.1 Accessibility. The system design shall consider the maintainability factors peculiar to the specific equipment to be used in the facility. Facility design shall provide for routine maintenance, repair, or replacement of equipment subject to failure.

3.2.5.2.2 Testing. The design shall include provisions for periodic testing of monitoring, surveillance, and alarm systems.

3.2.5.3 Availability. The new substation shall have a goal of 100 percent availability avoid curtailed operations during planned maintenance of the electrical utility equipment.

\subsubsection{Environmental Conditions}

The systems, subsystems, and components required as part of the Phase I Privatization Facilities Electrical Power Project shall be designed to withstand the environmental conditions specified in this section.

3.2.6.1 External--Weather Related. All systems, subsystems, and components shall be designed to withstand the natural environments of the Hanford Site, thermal effects of the soil shall also be considered for the system's buried portions. All systems, subsystems, and components must be able to withstand the environmental conditions as outlined in Climatological Data Summary 1995, with Historical Data (PNNL 1996).

3.2.6.2 External--Natural Induced Forces. All required systems, subsystems, and components shall comply with the design loads for non-reactor structures specified in Hanford A/E Standards - Architectural/Civil (KEH 1995b).

\subsubsection{Transportability}

Where a special transportation vehicle is required for the transportation of a major equipment, both the equipment and the vehicle shall meet the requirements of the Department of Transportation regulations and requirements.

\subsubsection{Flexibility and Expansion}

The system design shall consider the ability to expand the substation system to accommodate future (TBD) loads. The substation system shall also be compatible with the existing 200 Areas electrical distribution system to allow interconnection of the two distribution systems. 
WHC-SD-WM-DRD-011

Revision 0

\subsubsection{Portability}

This section is not applicable to the Phase I Privatization Facilities Electrical Power Project.

\subsection{DESIGN AND CONSTRUCTION}

Figure 3-1, a System Requirements Hierarchy Diagram, is provided to illustrate system components and related requirements.

\subsubsection{Materials}

In general, criteria for the Nonreactor Facilities from DOE Order 6430.1A (DOE 1989) shall be applicable. The National Electrical Safety Code (IEEE 1993b) shall be applicable to the transmission, transformation and distribution systems. The electrical equipment in the switchgear building shall also comply with requirements of the National Electric Code (NFPA 1996a). Other specific codes and standards are identified in specific sections.

\subsubsection{230 kV Transmission System.}

3.3.1.1.1 Connections to Existing 230-kV Lines. The RL $230 \mathrm{kV}$ transmission system shall be modified to add a new $230-13.8 \mathrm{kV}$ substation between the A-8 substation (251-W) and the A-22 switchstation (Ashe Tap). The A-8 to A-22 line shall be split at a point to be determined and connected to two new transmission lines originating from the new substation. Reference Construction Data and Stringing Instructions and Plan and Profile drawings, Midway-251 (A-2 Section) and 251-Ashe Tap (A-8 Section), $230 \mathrm{kV}$ Single Circuit Transmission Line W.O. 930-904 (BPA 1980), for existing transmission line specifications.

3.3.1.1.1.1 Tie-In. Existing tangent transmission structures will be removed and replaced with turning transmission towers to route the lines to the new substation. The new $230 \mathrm{kV}$ substation will be located in the 200 Areas, close to the privatization facilities. The new $230 \mathrm{kV}$ transmission lines will be tapped into the existing RL $230 \mathrm{kV}$ transmission system and routed to the new substation.

3.3.1.1.1.2 Removal of Unused Segments. Structures for the abandoned spans of the A-8 to A-22 transmission line shall be razed and components (conductor, insulators, towers, etc.) stored, recycled, or otherwise appropriately disposed. The abandoned corridor shall be environmentally restored in accordance with NEPA (CFR 1992).

3.3.1.1.2 Control and Alarms. Controls and alarms for the transmission lines are discussed in Section 3.3.1.2.1 and will be provided at the new substation and existing remote substations $251-\mathrm{W}, 151-\mathrm{KW}$, and Ashe. 


\section{WHC-SD-WM-DRD-011 \\ Revision 0}

Figure 3-1. Phase I Privatization Facilities Electrical Power System Design Requirements Hierarchy Diagram.

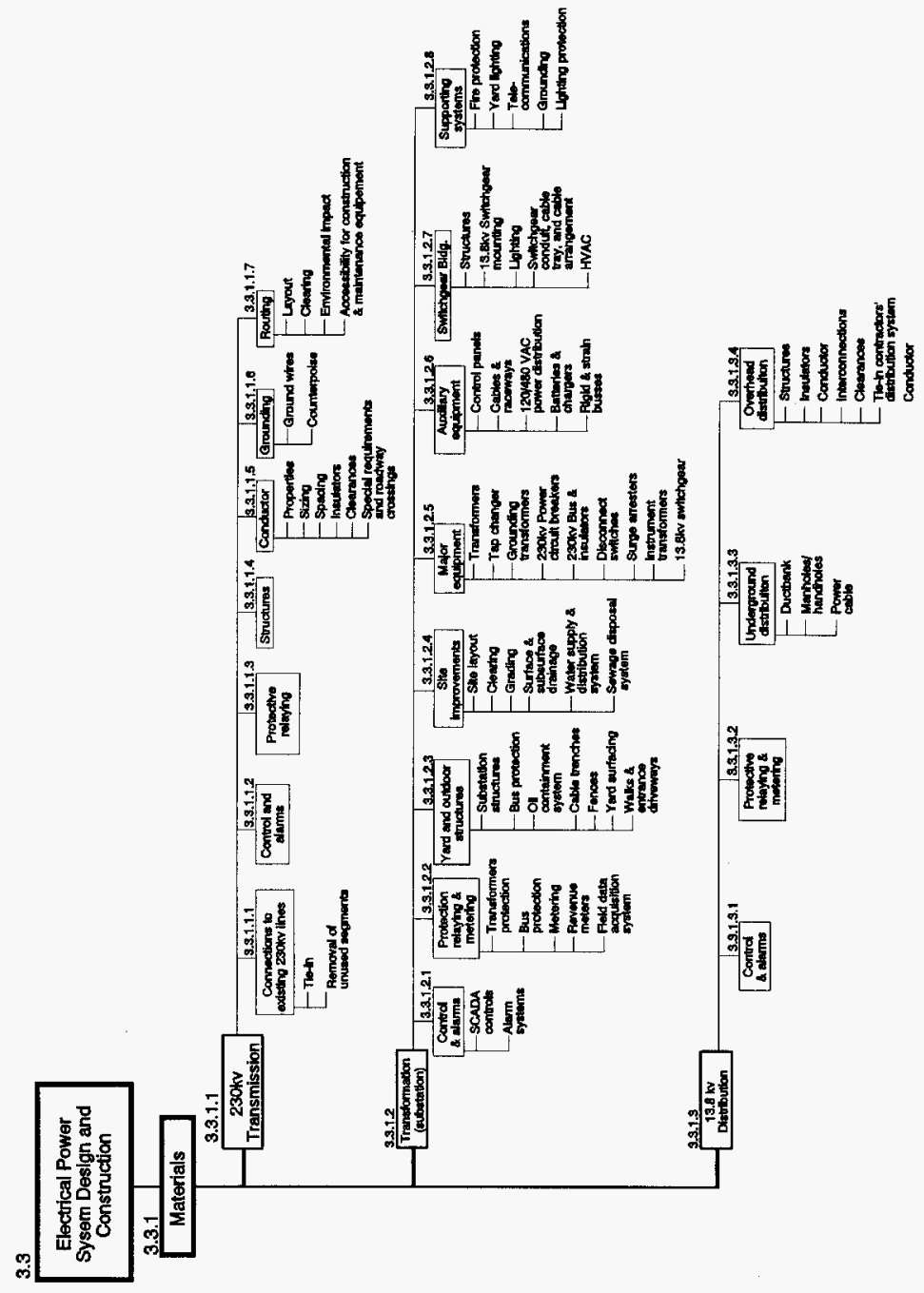




\section{WHC-SD-WM-DRD-011 \\ Revision 0}

3.3.1.1.3 Protective Relaying. A direct underreach permissive overreach transfer trip relay system will be used as primary protection for the $230-\mathrm{kV}$ transmission lines.

Microwave or fiber optic telecommunications can be used for the communication channels. The transmission line protection shall be compatible with the system described in Microwave Transfer Trip Relay Project Final Definitive Report (WHC 1991). Backup protection will be provided by directional distance and directional ground overcurrent relays.

3.3.1.1.4 Structures. The line support structures shall be self-supporting (no guys) and consist of transmission line terminating structures and strain bus structures. The major design loads are the tension and wind forces from the overhead ground wires and conductors. Line support structures shall be designed for a simultaneous application of vertical, transverse, and longitudinal forces imposed by overhead ground wires and conductors.

The line support structures shall comply with the requirements of ASCE 52 (ASCE 1988) and the current edition of the UBC. Transmission pole structures shall comply with the requirements of ASCE 72 (ASCE 1993). Design loads not defined in the above documents shall be per ICF Kaiser Hanford Company (ICF KH) Architect/Engineer (A/E) Standard GC-LOAD-01 (KEH 1996), Rev. I, the UBC, and ASCE 7 (ASCE 1995). Basic design loads shall include dead, live, snow, wind, seismic, icing, and line tension.

\subsection{Conductor.}

3.3.1.1.5.1 Properties. Conductors shall be suitable for the location, use, and voltage.

3.3.1.1.5.2 Sizing. Conductor shall be selected to meet the required electrical load to be served, voltage drop, mechanical strength, and the environmental degradation effect.

3.3.1.1.5.3 Spacing. Adequate clearance from the line conductor to the tower or to ground must be maintained so that the full effectiveness of the insulating structure can be obtained. Necessary conductor sag shall be provided in accordance with IEEE/ANSI C2 (IEEE 1993a).

3.3.1.1.5.4 Insulators. The insulation requirements of the transmission lines are to be determined by lightning and switching transients and not necessarily normal frequency voltages. Insulators shall be in accordance with ANSI Standards C29.1 (ANSI 1988) through C29.9 (ANSI 1983). Line insulation design shall be in accordance with ANSI C84.1 (ANSI 1995) and IEEE 1313 (IEEE 1993e).

3.3.1.1.5.5 Clearances. Conductor clearances to ground and foreign objects or other features of the terrain shall be not less than those established by the National Electrical Safety Code, IEEE/ANSI C2 (IEEE 1993a). Existing transmission line characteristics (BPA 1980) shall be considered to connect the new transmission lines for the new substation. 
3.3.1.1.5.6 Special Requirements and Roadway Crossings. Vertical clearances of conductors above roadway, rail or water surfaces shall be in accordance with IEEE/ANSI C2 (IEEE 1993a). Warning road crossing structures shall be provided when transmission line crossing major roadways.

\subsection{Grounding}

3.3.1.1.6.1 Ground Wires. Ground wires with sufficient mechanical strength shall be located to shield the line conductors adequately from direct lightning strokes. The selection of the size, arrangement, and mechanical strength of ground wires (sometimes called "static" wires) is of paramount importance to the design of the line. The ground wires shall have characteristics that are practically the same as the line conductors. Adequate clearances from ground wires to conductors must be maintained, especially at the midspan, to prevent flashover to the conductors up to the protective voltage level used for the line design. The selection of the ground wires should be based on mechanical rather than electrical considerations. Ground wires shall be placed to intercept lightning strokes. Grounding of power lines shall be in accordance with IEEE 1048 (IEEE 1990e).

3.3.1.1.6.2 Counterpoise. Tower-footing resistances should be as low as economically justified. The degree that low tower-footing resistances can be obtained depends upon the local soil conditions. Due to the high soil resistivity on the Hanford Site adequate tower-footing resistance is obtained through the use of a continuous counterpoise on the existing RL $230 \mathrm{kV}$ transmission lines. The counterpoise is a practical means of reducing the tower-footing resistance by increasing the area of earth in contact with the grounding system. If counterpoise is used, it shall be commensurate the existing transmission system (BPA 1980).

3.3.1.1.7 Routing. The selection of the routing for the transmission system shall consider the conditions listed in DOE Order 6430.1A (DOE 1989), as applicable.

3.3.1.1.7.1 Layout. The following points shall be considered when selecting and orienting the substation on the site: (1) incoming and outgoing lines, (2) access, (3) impact on surrounding area, (4) Electrical line crossings, (5) roadway crossings, and (6) utility corridor designation.

3.3.1.1.7.2 Clearing. Complete removal and disposal of all brush, roots, and other objects resting on or protruding through the surface where foundations are to be placed for transmission line structures. Trees that have the capability of growing beyond the minimum prescribed distance to the conductors shall be completely removed.

3.3.1.1.7.3 Environmental Impact. The substation design will be evaluated for environmental impact (CFR 1992) and will require necessary permitting (WHC 1996a). IEEE 1127 (IEEE 1990c) shall be followed for this process. 
3.3.1.1.7.4 Accessibility for Construction and Maintenance Equipment. Siting considerations shall include accessibility to cranes and other heavy equipment. All parts to be examined or inspected during operation shall be arranged so as to be accessible to authorized persons by the provision of adequate climbing spaces, working spaces, working facilities, and clearances between conductors.

3.3.1.2 Transformation (Substation). The substation system shall transform the $230 \mathrm{kV}$ transmission system to the $13.8 \mathrm{kV}$ distribution system. The new electrical substation system shall have a goal of 100 percent availability so as to avoid curtailed operations to the privatization contractor, during planned maintenance of electrical utility equipment. The substation system shall also be highly reliable so as to reduce the consequences of unplanned outages to the privatization contractor facilities. The substation system shall consider further expansion due to future (TBD) facilities. The substation system shall also be compatible with the existing 200 Areas electrical distribution system to allow interconnection of the two distribution systems. Also, electrical power system analyses shall commensurate IEEE 399 (IEEE 1990a). Reliability of the electrical power system. shall be evaluated per IEEE 493 (IEEE 1990b).

\subsection{Control and Alarms.}

3.3.1.2.1.1 SCADA Controls. The new $230 \mathrm{kV}$ and $13.8 \mathrm{kV}$ systems will be controlled and monitored by the existing Electrical Utility Hanford Site SCADA system. The Hanford Site SCADA system controls and monitors the electrical utility infrastructure system. The SCADA system at the new substation will allow the electrical utility dispatcher to operate $230 \mathrm{kV}$ and $13.8 \mathrm{kV}$ breakers, motor operated disconnect switches, and other associated controls. The SCADA system will allow the electrical utility dispatcher to monitor conditions at the new substation. The SCADA system at the new substation shall be compatible with the SCADA system as specified in Supervisory Control an Data Acquisition (SCADA) Computer System, Acquisition Plan \#WHC-95-353936 (KEH 1995).

3.3.1.2.1.2 Alarm Systems. Local Annunciator/Alarm system shall be provided to allow for notification when abnormal operating parameters are reached.

\subsection{Protective Relaying and Metering}

3.3.1.2.2.1 Transformer Protection. Primary protection for transformers will be differential protection. Back-up protection will consist of overcurrent protection on the 230 $\mathrm{kV}$ terminals. Relaying shall be provided commensurate with IEEE Standards C37-series (IEEE 1995a), C57-series (IEEE 1995b), and 242-1986 (IEEE 1986b).

3.3.1.2.2.2 Bus Protection. Normal bus protection for the $230 \mathrm{kV}$ buses will be provided by high impedance voltage operated differential relays that form part of the transformer protection. Normal bus protection for the $13.8 \mathrm{kV}$ buses will also be provided 
by high impedance voltage operated differential relays. Protection shall be commensurate with IEEE Standard 242-1986 (IEEE 1986b).

3.3.1.2.2.3 Metering. Metering shall be provided to measure the performance and status of the electrical system. Metering shall be commensurate with IEEE Standard C12-1993 (IEEE 1993b) and Hanford A/E Standards - Electrical (KEH 1995c).

3.3.1.2.2.4 Revenue Meters. Metering of power demand and energy consumption shall be provided on the secondary of the main transformer, see section 3.3.1.3.2.1.2.

3.3.1.2.2.5 Field Data Acquisition System. Inputs to the Field Data Acquisition System (FDAS) to monitor electrical energy use and transmit data to a central location (by a voice grade telecommunication signal--modems) for analysis, shall be provided from the secondary side of the main transformer, see section 3.3.1.3.2.1.3.

\subsection{Yard and Outdoor Structures}

3.3.1.2.3.1 Substation Structures. Substation structures shall be self-supporting (no guys) and may be classified into two types according to function and design approach: line support structures and equipment support structures. Line support structures consist of transmission line terminating structures and strain bus structures. The major design loads are the tension and wind forces form the overhead ground wires and conductors. Equipment support structures consist of bus support, switch stands, lightning arrester stands, instrument transformer stands, etc. These structures are usually designed as cantilever columns with wind and short circuit forces being the primary design load.

The substation structures shall comply with the requirements for loadings given in ICF KH A/E Standard GC-LOAD-01, Rev.1 (KEH 1996), using Safety Class 3 criteria, the UBC (Seismic Zone 2B), ASCE 7 (ASCE 1995), and the actual equipment loads. Basic design loads shall include dead, live, snow, wind, and seismic. The structure shall conform to the design requirements of the UBC and standards such as American Institute of Steel Construction (AISC 1989) allowable stress design, and ACI 318 (ACI 1995).

3.3.1.2.3.2 Foundations, Foundations will be designed to properly support substation equipment and structures. All foundations (excluding the switchhouse building foundation) will be spread footings or auger type drilled caissons. The power transformers foundations will be of a special design depending on the type of oil containment system used.

Foundations shall be designed after an adequate soil investigation has been conducted by a qualified soils engineer. The design shall consider the structure loads, the subsurface soil conditions, and the alternative foundation types to best support the foundation loads, limit total and differential settlements, and shall consider overall construction costs. Soils investigations shall comply with the requirements given in DOE order 6430.1A (DOE 1989), Section 0201 . The foundation design shall comply with the UBC. 
3.3.1.2.3.3 Oil Containment System. A system shall be designed for collection, by gravity drain, and containment of oils spills from power transformers and other sources at the substation and then transported to a safe storage area remote to the equipment in order to minimize potential fire hazard and damage to the environment. The spill containment system will be of sufficient capacity to completely collect and contain a volume of oil that is equal to the entire volume of oil contained in the power transformers. Design measures will include a collection basin, a system to prevent spilled oil from entering and contaminating surrounding soil, and an alarm system to alert operating personnel to potential oil spill problems.

The oil containment systems shall comply with 40 CFR 112 (CFR 1996) and Factory Mutual (FM) and IEEE 980 (IEEE 1984).

3.3.1.2.3.4 Cable Trenches. The cable trench system will be designed based on the specific substation requirement and will consider future (TBD) expansion/growth of the substation facilities. The cable trench will terminate into a re-enforced concrete pullbox that will be attached to the switchhouse building foundation.

Cable trenches terminating at the substation shall be concrete encased with cable ducts as required for the existing design and necessary future (TBD) expansion. The recommended practices are provided in ANSI/NEMA TC8 Standard (ANSI 1990b).

3.3.1.2.3.5 Fences. Substations shall be enclosed by fences to prevent the entrance of animals and unauthorized persons who might, willfully or through negligence, damage equipment or injure themselves. Fences will also be provided to enclose individual pieces of outdoor substation apparatus having exposed live parts less than the minimum prescribed distance above ground.

The fence will be appropriately grounded to the substation ground bus. Entrance to the substation will be provided through a $6.1-\mathrm{m}(20-\mathrm{ft})$ double swing gate or equivalent/appropriate design.

Perimeter fencing for the substation and specific equipment isolation fencing shall be designed following the guidance of Section 0280 of DOE Order 6430.1A (DOE 1989). Fencing materials shall comply with IEEE 1119 (IEEE 1988).

3.3.1.2.3.6 Yard Surfacing. Either all or part of each substation shall be surfaced with crushed stone to provide an increased electrical resistance between the soil and the feet of personnel as well as a stable driving and walking surface. The material shall be tested, selected, and thickness designed for its electrical resistivity and its ability to provide stabilization to the soil.

3.3.1.2.3.7 Walks and Entrance Driveways. The substation must be provided with a driveway for vehicular access for operating, maintenance, or construction activities. Walks 
must be provided between points subject to continual foot traffic to afford convenience and safety to the operating and maintenance personnel.

Walks shall be provided as required by DOE Order 6430.1A (DOE 1989), Section 0250-2. Roads, parking areas, and paving shall comply with DOE Order 6430.1A (DOE 1989), Sections 0250-3, 0250-4, and 0250-5.

3.3.1.2.4 Site Improvements. Improvements to the site will be needed to ensure that the location of the substation will have adequate water and sewer utilities, access, consideration of the impact on surrounding areas, and ensure a proper drainage system.

3.3.1.2.4.1 Site Layout. The following points shall be considered when selecting and orienting the substation on the site: (1) incoming and outgoing lines, (2) drainage, (3) access, and (4) impact on surrounding area.

The selection of the site for the substation complex shall consider the conditions listed in DOE Order 6430.1A (DOE 1989), Division 2, Section 0200-1.1, as applicable.

3.3.1.2.4.2 Clearing. Complete removal and disposal of all brush, roots, and other objects resting on or protruding through the surface.

3.3.1.2.4.3 Grading. The substation yard shall be graded and sloped to provide surface drainage, level areas for equipment, erosion control, elimination of standing water, and diversion of water from the site to the natural drainage area. Proper grading also improves the appearance of the station and facilities grounds maintenance.

Grading of the selected site(s) shall conform to the requirements of DOE Order 6430.1A (DOE 1989), Sections 0210 and 0220, as applicable.

3.3.1.2.4.4 Surface and Subsurface Drainage. The drainage systems shall be designed to effectively remove surface water from the substation site as well as removal and containment of oil that might create an environmental or fire hazard. The drainage ditches shall be designed so as not to alter the general drainage pattern of the substation site. The substation will be designed to incorporate an oil spill containment system. Surface and subsurface drainage shall conform to the requirements of DOE Order 6430.1A (DOE 1989), Section 0270-2.

3.3.1 2.4.5 Water Supply and Distribution System. Water shall be provided if: (1) the substation is partly attended and an established water system exists in the immediate vicinity of the substation and (2) a water or fog type fire protection system is used. Water shall be secured from a local utility where practical. 


\section{WHC-SD-WM-DRD-011 \\ Revision 0}

System design shall comply with the requirements of DOE Order $6430.1 \mathrm{~A}$ (DOE 1989), Section 0266, NFPA 24 (NFPA 1995), UBC, and Washington Administrative Code, Chapter 246-290 (WAC 1995a).

3.3.1 2.4.6 Sewage Disposal System. If the substation will be partially attended then a water-carried sewage disposal system shall be provided, if water is available. No untreated sewage shall be discharged onto the surface of the ground or into any surface stream. Where utility sanitary sewers are available the connection shall be made to the existing sewer lines.

The system shall be designed and constructed to comply with the requirements of the WAC, Chapter 248-96 (WAC 1995b) and the Benton-Franklin District Board of Health. An alternate to an onsite sewage disposal facility may be a holding tank sewage system, after an appropriate investigation. The sanitary waste water collection system shall comply with the requirements of DOE Order 6430.1A (DOE 1989), Section 0270-1. Excavations, trenching, and shoring shall comply with 29 CFR 1926, Subpart P (CFR 1995b).

\subsection{Major Equipment.}

3.3.1.2.5.1 Transformers. Two transformers shall be used as two main service transformers for a double-ended customer service substation. The transformers shall step down $230 \mathrm{kV}, 60 \mathrm{~Hz}, 3$-phase transmission power to $13.8 \mathrm{kV}, 60 \mathrm{~Hz}, 3$-phase distribution power. The two transformers shall be subjected to momentary parallel operations during load transfer from one transformer to another. The primary winding shall be wye solidly grounded connected and the secondary winding shall be a delta connected. The secondary connection shall be compatible to the existing 200 Areas $13.8 \mathrm{kV}$ distribution system to accommodate interconnecting the distribution systems. The transformers shall be oil immersed, sealed tank, outdoor types, each capable of delivering a minimum of $40 \mathrm{MW}$.

The transformer design shall be in accordance with IEEE/ANSI C37.2 (IEEE 1995a), C57.12, C57.12.10, C57.12.70, C57.12.90, C57.13, C57.98 Standards (IEEE 1995b). Protective relaying shall be in accordance with IEEE C37.91 (IEEE 1985).

Electrical equipment cooling material shall be handled in accordance with 29 CFR 1910.1200. Dikes and drainage provisions shall be built as required by the local SPCC in conformance with 40 CFR 112 (CFR 1996). Oil-filled transformers installed near buildings shall comply with FM 5-4/14-8.

3.3.1 2.5.2 Tap Changer. An on load tap changer may be necessary to provide necessary voltage regulation. The tap changer design shall be in accordance with IEEE/ANSI C57.12.10 and C57.131 (IEEE 1995b).

3.3.1.2.5.3 Grounding Transformers. A $13.8 \mathrm{kV}$ grounding (zig-zag) transformer shall be installed on the secondary of each main service transformer to provide a grounding 


\section{WHC-SD-WM-DRD-011 \\ Revision 0}

source for protective equipment. A grounding resistor shall be installed to limit the ground fault current and over voltages on a delta connected $13.8 \mathrm{kV}$ system.

The following standards shall be used for the design - IEEE/ANSI 32 (IEEE 1972), IEEE/ANSI C57.13 (IEEE 1995b), and IEEE/ANSI C62.92 (IEEE 1995d).

3.3.1.2.5.4 $230 \mathrm{kV}$ Power Circuit Breakers. Two main and one tie power circuit breakers will be part of the $230 \mathrm{kV}$ switchyard. Power circuit breakers shall be rated $230 \mathrm{kV}, 3$-phase, $60 \mathrm{~Hz}$, and provide power protection/control to the $230 \mathrm{kV}$ line and substation transformers located in the $230 \mathrm{kV}$ switchyard.

Rating of each power circuit breaker shall meet the requirements of IEEE/ANSI Standards C37.04, C37.06 and C37.12 (IEEE 1995a). The circuit breakers shall be capable of being isolated from the substation buses for the purposes of replacement, modification, repair, or routine preventive maintenance while the rest of the substation remains energized. Control power shall be 125 VDC.

3.3.1.2.5.5 $230 \mathrm{kV}$ Bus and Insulators. Rigid bus, insulators, connectors, and jumper will be used to make up the $230 \mathrm{kV}$ bus system. The dry flashover voltage of the insulators shall not be less than the recommended levels indicated in IEEE/ANSI C2 (IEEE 1993a).

3.3.1.2.5.6 Disconnect Switches. Disconnect switches are required for transmission line, circuit breaker, and transformer isolation. For the purposes of isolating sections of the $230 \mathrm{kV}$ lines, motor operated disconnect switches will be used. For all other purposes, manually, grouped operated switches will be used. The disconnect switches shall be 3-pole, ganged operated.

Air break disconnect switches required for isolation of substation equipment shall meet the IEEE/ANSI Standards C37.30, C37.32, C37.33, C37.34, and C37.35 (IEEE 1995a). Control power shall be 125 VDC.

3.3.1 2.5.7 Surge Arresters. Station class surge arresters will be used for protection of the power transformers. These arresters will also provide surge protection to other equipment at the substation, provided the arrester is in operation. These arresters will be located as close to the transformer bushing as possible. In order to protect from steep front incoming surges (lighting) and as a further protection when part of the substation insulation is isolated from the protective influence of the surge arresters, (e.g., where the transformer $230 \mathrm{kV}$ switch is open). Surge arresters will also be installed at the line entrance to the substation.

The station class surge arresters required to protect the power transformers shall be in accordance with IEEE/ANSI Standard C62.11 (IEEE 1993d). 
3.3.1.2.5.8 Instrument Transformers. Oil-filled outdoor potential and current transformers (PT and $\mathrm{CT}$ ) will be used for protective relaying, monitoring, and non-revenue metering. The instrument transformers shall be in accordance with IEEE/ANSI C57.13 (IEEE 1995b).

3.3.1.2.5.9 $13.8 \mathrm{kV}$ Switchgear. A indoor switchgear $13.8 \mathrm{kV}$, 3-phase, 3-wire, 60 $\mathrm{Hz}$, split bus, and double ended feed, will be installed in the switchgear building. The switchgear assembly shall consist of metal-clad, free-standing, vertical dead-front structures, indoor type, double ended with two incoming breakers and one tie breaker. Each bus shall have a minimum of two feeder breakers with the capability of expansion (additional spares and spaces).

The $13.8 \mathrm{kV}$ Switchgear shall be in accordance with IEEE/ANSI C37.20 (IEEE 1995a). The Switchgear device function numbers shall be in accordance with IEEE 315 and IEEE 315A (IEEE 1992).

\subsection{Auxiliary Equipment}

3.3.1.2.6.1 Control Panels. Control panels will generally consist of devices such as relays, annunciators, and indicating lights. The panels shall be in accordance with ANSI C2 (IEEE 1993a), NFPA 70 (NFPA 1996), NEMA 250 (NEMA 1991a), NEMA ICS6 (NEMA 1993) and the UBC.

3.3.1.2.6.2 Cables and Raceways. Raceway system shall provide a continuous enclosure for protecting cables against mechanical damage and prevent electrical faults from spreading to undamaged cables. A complete raceway system above and below grade shall be designed for all control and power cables. This will include the cable trench, duct bank, and any necessary manholes.

The raceway system, as necessary, shall be provided in accordance with NFPA 70 (NFPA 1996). Future expansion (TBD) provisions shall be provided. Raceway system including duct work shall meet requirements of appropriate NEMA standards.

Selection of the power cables shall be made with due cognizance to ambient temperature, normal and emergency loading, system fault levels, voltage drops, etc. The power cables shall meet the requirements of NEMA standards WC5 (NEMA 1992), WC7 (NEMA 1988a), and WC8 (NEMA 1988b) as applicable.

3.3.1.2.6.3 120 and 480 Vac Power Distribution. The station service equipment, as needed, may require $120 / 240 / 480 \mathrm{~V}$ single/three phase power supply that shall be obtained from a corresponding distribution transformer sized and wired in accordance with appropriate IEEE/ANSI C2 (IEEE 1993a) and NFPA 70 (NFPA 1996) standards. A dual electrical power feed shall be provided so that loss of one feed shall not cause shutdown of the entire system. 
3.3.1.2.6.4 Batteries and Chargers. Station control batteries provide sources of auxiliary power for tripping and closing circuit-interrupting devices, operating protective relays, pilot/indicating lights, and emergency lights. A battery charger will maintain the battery under normal operation by applying a float charge. The general requirement of the $125 \mathrm{Vdc}$ power is to supply substation class loads that require $125 \mathrm{Vdc}$ to operate. The $125 \mathrm{Vdc}$ distribution panels, fed via the battery banks, shall supply power to loads such as the $230 \mathrm{kV}$ power circuit breakers, $13.8 \mathrm{kV}$ switchgear, and associated protective monitoring and control devices. The battery system shall be lead acid batteries suitable for the substation environment. The $125 \mathrm{Vdc}$ batteries shall be sized in accordance to IEEE Standard 485 (IEEE 1983). Installation design of the battery system shall be in accordance to IEEE Standard 484 (IEEE 1987).

3.3.1.2.6.5 Rigid and Strain Buses. Rigid and strain buses are often subjected to increasing fault currents and resulting higher mechanical stresses as the system grows in generation and transmission capacity. Characteristically higher ampacity requirements prevail for new bus installation. The design of a rigid bus system shall consider: (1) bus location in the substation and its proximity to other equipment (clearances), (2) future substation expansion; conductor selection (ampacity), (3) short circuit conditions, (4) wind and ice load, (5) insulator strength, conductor sag, aeolian vibration, conductor expansion, (6) location of conductor couplers, and (7) corona and radio influence. The bus system should be carefully planned by considering these aspects and other factors as they develop. The bus system shall have sufficient mechanical strength to withstand short circuit stresses in the environment where it is located. The metal-enclosed bus system shall be provided in accordance with IEEE/ANSI Standard C37.23 (IEEE 1995a).

3.3.1.2.7 Switchgear Building. A switchgear building shall provide housing for $13.8 \mathrm{kV}$ switchgear and relay panels, $125 \mathrm{VDC}$ distribution system, and communication equipment.

3.3.1.2.7.1 Structures. A suitable prefabricated metal building shall be provided in accordance with UBC Seismic Zone $2 B$ criteria.

3.3.1.2.7.2 13.8 kV Switchgear Mounting. The switchgear will be mounted indoors in accordance with UBC Seismic Zone $2 \mathrm{~B}$ criteria.

3.3.1.2.7.3 Lighting. Lighting level shall conform to the requirements of the IES Lighting Handbook as required by DOE Order 6430.1A (DOE 1989). Protective lighting shall be provided for security purposes, as required, in accordance with DOE Order 6430.1A (DOE 1989). Lighting power budget shall be determined in conformance with ASHRAE Standard 90.1 (ASHRAE 1989). Exit and emergency lighting systems shall comply with NFPA 101 (NFPA 1994).

3.3.1.2.7.4 Switchgear Building Conduit, Cable Trays, and Cable Arrangement. The raceway system, including trays, conduits, and trenches shall permit an orderly 
arrangement of cables from the switchyard and minimize the fire hazard. Installation shall be free from rags, paper, dirt, and other foreign matter that might collect and ignite. Cable fill of raceways shall not exceed the limits specified in NFPA 70 (NFPA 1996).

Flexible steel conduit shall be used for connection to equipment subject to vibration and connection from junction boxes to recessed lighting fixtures. Rigid steel conduit or intermediate metal conduit shall be used in locations classified as hazardous by NFPA 70 (NFPA 1996). Rigid steel conduit and intermediate metal conduit shall meet requirements of NEMA RN1 (NEMA 1989). Nonmetallic conduit where allowed by NFPA 70 (NFPA 1996) shall meet requirements of NEMA TC2 (NEMA 1990a) and NEMA TC8 (NEMA 1990b). Nonmetallic conduit shall not be used in electromagnetically sensitive areas. The cable tray system shall meet requirements of NEMA VE-1 (NEMA 1991b).

3.3.1.2.7.5 Heating, Ventilation and Air Conditioning (HVAC). The switchhouse will provide a clean, dry, temperate atmosphere for operating personnel when present and indoor electrical equipment such as $13.8 \mathrm{kV}$ switchgear, switchboards, batteries, communication apparatus, etc. HVAC shall be provided in accordance with ASHRAE Standard 90.1 (ASHRAE 1989).

\subsection{Supporting Systems}

3.3.1.2.8.1 Fire Protection. Fire protection provisions shall comply with DOE 6430.1A (DOE 1989), Section 110-6 and 1530, and RLID 5480.7 (DOE 1993b) except NFPA 101 (NFPA 1994) shall be used in lieu of 29 CFR 1910 (CFR 1995a). In the event of conflict, RLID 5480.7 shall take preference.

3.3.1.2.8.2 Yard Lighting. Sufficient yard lighting is necessary for maintenance of equipment and personnel safety. Illumination will be provided in the substation for the benefit of operating personnel in maintenance, inspection, and operation of such items as power circuit breakers, disconnecting switches, power transformers, instrument transformers, and similar apparatus. Convenience outlets shall be provided as a supply for extension lights, small tools, and test equipment required in substation construction and maintenance. The lighting shall be designed in accordance with IES Handbook (IES 1993) recommendations as required by DOE Order 6430.1A (DOE 1989).

3.3.1.2.8.2.1 Lighting Sources. For the yard lighting, maximum use shall be made of high-efficiency HID lamps such as metal halide, high-pressure sodium, or low-pressure sodium vapor lamps.

3.3.1.2.8.2.2 Energy Conservation. Minimum lighting, high efficiency lamps, and energy-efficient ballasts shall be used for energy conservation. 
3.3.1.2.8.2.3 Emergency Lights. All or part of the high-level lights in the yard shall have provision for switching from one source to the other. This would be considered as emergency lights.

3.3.1.2.8.2.4 Receptacles. 120 VAC and 480 VAC electrical receptacles shall be provided as required.

3.3.1.2.8.2.5 Ground Fault Circuit Interrupter. Ground fault circuit interrupter protection shall be provided at outdoor and wet locations.

3.3.1.2.8.3 Telecommunications. Telecommunications in the switchhouse shall include the following services: (1) voice grade circuits for basic site telephone system, (2) voice grade circuits for the Field Data Acquisition System (FDAS) as specified in Description of FDAS - End-Use Load and Conservation Assessment Program, DOE/BPA/13795-4 (BPA 1985), (3) Fiber optic/microwave circuits for the Supervisory Control and Data Acquisition (SCADA) system as specified in Supervisory Control an Data Acquisition (SCADA) Computer System, Acquisition Plan \#WHC-95-353936 (KEH 1995), (4) voice grade circuit for the maintenance "MAG" lines as specified in Farinon Microwave End of Life Cycle, WHC-SD-GN-ER-20007 (WHC 1996b), and (5) Circuits for the Integrated Transfer Trip System (ITTS) as specified in Farinon Microwave End of Life Cycle, WHC-SD-GN-ER-20007 (WHC 1996c).

3.3.1.2.8.4 Grounding. A complete ground grid system is required for personnel and equipment safety. The grounding system shall be in compliance with IEEE/ANSI C2 (IEEE 1993a) and IEEE 142 (IEEE 1991). Recommended design considerations are provided in IEEE 80 (IEEE 1986a). Grounding connections shall comply with IEEE 837 (IEEE 1989).

3.3.1.2.8.5 Lightning Protection. Lightning protection system will be used in the substation to protect equipment, buses, lines, and the control building against lightning surges. Lightning protection system shall comply with NFPA 780 (NFPA 1995) and NFPA 70 (NFPA 1996). A risk assessment shall be made using the guide in Appendix I of NFPA 780 (NFPA 1995) to determine the risk of loss due to lightning.

3.3.1.3 $13.8 \mathrm{kV}$ Distribution System. The new electrical distribution system shall be reliable and flexible and provide $13.8 \mathrm{kV}$ three-phase, $60 \mathrm{~Hz}$ power to the privatization contractor. The distribution lines to the privatization contractor service point shall be dedicated, express feeders. The electrical distribution system shall also be compatible with the existing 200 Areas electrical distribution system to allow interconnection of the two distribution systems. Distribution system design shall be commensurate with IEEE 141 (IEEE 1993c). 
3.3.1.3.1 Controls and Alarms. The location of the control devices and alarms shall be readily accessible to personnel. Instruments, relays, and other devices requiring reading or adjustments should be so placed that work can be performed from the working space.

\subsection{Protective Relaying and Metering.}

3.3.1.3.2.1 Distribution Line Protection. Distribution line protection will consist of phase and overcurrent relays. The distribution line protection shall be provided in accordance with ANSI/IEEE Standard 242 (IEEE 1990a) and WHC-SD-LL-ES-034 (WHC 1993).

3.3.1.3.2.1.1 Metering. Metering is needed to measure the performance and status of the electrical system. Metering shall be provided to allow proper distribution of electrical energy costs to individual customers and to provide historical data on which to base electrical energy standards for the product produced or the service offered, and evaluate performance against that standard. Metering shall be commensurate with IEEE Standard C12-1993 (IEEE 1993b) and Hanford A/E Standards - Electrical (KEH 1995c).

3.3.1.3.2.1.2 Revenue Meters. Metering of power demand, energy consumption and reactive consumption shall be provided on each $13.8 \mathrm{kV}$ main incoming circuit breaker and each $13.8 \mathrm{kV}$ line feeder circuit breaker. Separate metering of power demand and energy consumption shall be provided for the switchgear building. Pulse outputs from the revenue metering shall be connected to the Field Data Acquisition System.

3.3.1.3.2.1.3 Field Data Acquisition System. The FDAS is used to monitor electrical energy use and transmit data to a central location (by voice grade telecommunication signals--modems) for analysis. Performance characteristics and further explained in detail in Development and Transfer of Energy Use Monitoring Technology at Pacific Northwest Laboratory (PNL 1985), and Description of FDAS - End-Use Load and Conservation Assessment Program, DOE/BPA/13795-4 (BPA 1985).

\subsection{Underground Distribution}

3.3.1.3.3.1 Duct Bank. The duct bank system will be designed based on the specific substation requirement and will consider future (TBD) expansion/growth of the substation facilities to allow for additional distribution feeders. The duct bank will terminate at each distribution line service riser. The duck bank design shall conform to IEEE/ANSI C2 (IEEE 1993a) and ICF KH A/E Standard GE-UGPD-01 (KEH 1995d).

3.3.1.3.3.2 Manholes/Handholes. Manholes and handholes shall be designed to sustain all expected loads that may be imposed upon the structure. The design shall be in accordance with ANSI C2 (IEEE 1993a) ICF KH A/E Standard GE-UGPD-01 (KEH 1995d). 
3.3.1.3.3.3 Power Cable. Selection of the power cables shall be made with due cognizance to ambient temperature, normal and emergency loading, system fault levels, voltage drops, etc. The power cables shall meet the requirements of NEMA standards WC5 (NEMA 1992), WC7 (NEMA 1988a), and WC8 (NEMA 1988b) as applicable.

\subsection{Overhead Distribution.}

3.3.1.3.4.1 Structures. Wooden structures shall be used to support the overhead distribution conductors and associated hardware from the service riser to the privatization contractor site boundary. Guys are provided for wood structures subjected to forces in excess of their strength, such as structures in dead-end or heavy angle positions, and for other structures where conditions require rigidity that cannot be economically obtained by a self-supporting design. The wood structures and necessary hardware shall be in accordance with the applicable IEEE/ANSI Standards C135 series (IEEE 1994) and IEEE 751 (IEEE 1990d).

3.3.1.3.4.2 Insulators. Insulators shall be designed so that the ratio of their rated low-frequency dry flashover voltage to low-frequency puncture voltage is in conformance with applicable ANSI Standards ANSI C29.1 through C29.9.

3.3.1.3.4.3 Conductor. Adequate clearance from the line conductor to the structure or ground must be maintained so that the full effectiveness of the insulating structure can be obtained. The current rating of the conductors shall be adequate to serve the highest anticipated load without resulting in unsatisfactory voltage regulation.

3.3.1.3.4.4 Interconnections. Interconnections between overhead lines and $13.8 \mathrm{kV}$ switchgear shall be in accordance with ICF KH GE-UGPD-01 (KEH 1995d).

3.3.1.3.4.5 Clearances. The supply lines shall provide adequate clearances in accordance with ANSI C2 (IEEE 1993a) to ensure safety.

3.3.1.3.4.6 Tie-In Contractor's Distribution System. Existing line parameter details are available from the site utilities. The new design shall ensure matching corresponding properties at the tie-in points.

\subsubsection{Electromagnetic Radiation}

Not applicable. 
WHC-SD-WM-DRD-011

Revision 0

\subsubsection{Nameplates and Product Markings}

Equipment and any parts of that equipment to be used by personnel shall be identified with appropriate labels. Specific guidelines for addressing labeling considerations are contained in MIL-STD-1472D (ARMY 1994), Section 5.5.

\subsubsection{Workmanship}

TBD

\subsubsection{Interchangeability}

The system shall standardize the components used in the design to the maximum extent practicable.

\subsubsection{Safety}

The facility shall be designed in accordance with industrial safety requirements of OSHA, 29 CFR 1910 (CFR 1995a), 29 CFR 1926 (CFR 1995b), DOE Order 6430.1A (DOE 1989), NFPA codes 101 (NFPA 1994), 241 (NFPA 1993c), WAC 296-45 (WAC 1994), and WAC 296-46 (WAC 1990) shall be applied.

Fence safety clearances shall be in accordance with IEEE 1119 (IEEE 1988).

\subsubsection{Human Engineering}

Equipment to be used by personnel shall be designed or selected to accommodate body dimensions. The design of equipment for personnel shall accommodate a wide variety of body dimensions. It is generally recommended that equipment dimensions accommodate the fifth to ninety-fifth percentile of the user population. For recommended data representing these percentiles, see MIL-STD-1472D (ARMY 1994), Section 5.6.

\subsubsection{Nuclear control}

Not applicable. 
WHC-SD-WM-DRD-011

Revision 0

\subsubsection{Security}

3.3.9.1 Fencing. The primary means of ensuring security and public safety at substations is by erecting a suitable barrier, such as a fence. As a minimum, the fence shall meet the requirements of ANSI C2 (IEEE 1993a). Non-metallic fences shall present equivalent barriers to climbing or other unauthorized entry. A warning sign shall be displayed at all entrances indicating potential danger. Warning signs shall also be placed where overhead lines cross the fence and at given intervals along long runs of fence. Recommended clearances from substation live parts to the fence are specified in IEEE 1119 (IEEE 1988).

\subsubsection{Government Furnished Property Usage}

Not applicable.

\subsubsection{Computer Resource Reserve Capacity}

Not applicable.

\subsection{DOCUMENTATION}

TBD

\subsection{LOGISTICS}

\subsubsection{Supply/Support}

The system design shall, to the greatest extent practicable, use readily available parts and components.

\subsection{PERSONNEL AND TRAINING}

\subsubsection{Personnel}

TBD 
WHC-SD-WM-DRD-011

Revision 0

\subsubsection{Training}

TBD

\subsection{CHARACTERISTICS OF SUB-SYSTEM ELEMENTS}

Not applicable.

\subsection{PRECEDENCE}

TBD

\subsection{QUALIFICATION}

TBD

\subsection{STANDARD SAMPLE}

Not applicable. 
WHC-SD-WM-DRD-011

Revision 0

\subsection{QUALITY ASSURANCE PROVISIONS}

Inspections as defined in Section 4.3 shall be conducted during the design and development of each system to provide assurance of compliance with the requirements of this document.

\subsection{RESPONSIBILITY FOR INSPECTIONS}

TBD

4.2 SPECIAL TESTS AND EXAMINATIONS.

Not applicable.

\subsection{REQUIREMENTS CROSS REFERENCE}

TBD 


\section{WHC-SD-WM-DRD-011}

Revision 0

This page intentionally left blank. 


\subsection{PREPARATION FOR OPERATIONS}

All equipment shipping and handling, storage, calibration, and testing shall be in accordance with manufacturer's recommendations.

\subsection{NOTES}

\subsection{DEFINITIONS}

Emergency Power System: An independent reserve source of electric energy that, upon failure or outage of the normal source, automatically provides reliable electric power within a specified time to critical devices and equipment whose failure to operate satisfactorily would jeopardize the health and safety of personnel or result in damage to property.

Phase I Privatized Facilities: Facilities which are privately (rather than by the Government) developed, financed, constructed, owned, operated, and deactivated.

Raceway: An enclosed channel designed expressly for holding wires, cables, or busbars, with additional functions as permitted in the National Electrical Code (NFPA 1996a).

Standby Power System: An independent reserve source of electric energy that, upon failure or outage of the normal source, provides electric power of acceptable quality so that the user's facilities may continue in satisfactory operation.

\subsection{ABBREVIATIONS AND ACRONYMS}

The abbreviations and acronyms listed below are used in this specification.

A/E Architect Engineer

AASHTO American Association of State Highway and Transportation Officials

AC Alternating Current

ACI American Concrete Institute

AISC American Institute of Steel Construction

AMCA Air Movement Contractors Association

ANSI American National Standards Institute 


\begin{tabular}{ll} 
ASCE & American Society of Civil Engineers \\
ASHRAE & American Society of Heating Refrigeration and Air-Conditioning \\
& Engineers \\
AWG & American Wire Gage \\
BPA & Bonneville Power Administration \\
CFR & Code of Federal Regulations \\
CT & Current Transformer \\
DC & Direct Current \\
DOE & U. S. Department of Energy \\
DRD & Design Requirements Document \\
FDAS & Field Data Acquisition System \\
FM & Factory Mutual \\
HID & High Intensity Discharge \\
HVAC & Heating Ventilation and Air Conditioning \\
Hz & Hertz \\
IES & Illuminating Engineering Society \\
IEEE & The Institute of Electrical and Electronics Engineers \\
IPCEA & Insulated Power Cable Engineers Association \\
ITTS & Integrated Transfer Trip System \\
ICF KH & ICF Kaiser Hanford Company \\
kV & Kilovolt \\
kW & Kilowatt \\
NEC & National Electrical Code \\
NEMA & National Electrical Manufacturer Association \\
NESC & National Electrical Safety Code \\
NFPA & National Fire Protection Association \\
MBMA & Metal Building Manufacuters' Association \\
MIL-STD & Military Standard \\
MW & Mega Watt \\
OSHA & Occupational Safety and Health Administration \\
PNNL & Pacific Northwest National Laboratory \\
PT & Potential Transformer \\
RL & U.S. Department of Energy-Richland Operations Office \\
SCADA & Supervisory Control and Data Acquisition \\
SMACNA & Sheet Metal and Air Conditioning Contractors National \\
& Association \\
\hline
\end{tabular}


WHC-SD-WM-DRD-011

Revision 0

SPCC Spill prevention control and countermeasure

TWRS Tank Waste Remediation System

UBC Uniform Building Code

UCRL University of California Research Laboratory

UL Underwriter's Laboratories, Incorporated

WAC Washington Administrative Code

WHC Westinghouse Hanford Company

WNP Washington Power System Nuclear Plant

W.O. Work order 
WHC-SD-WM-DRD-011

Revision 0

This page intentionally left blank. 


\section{DISTRIBUTION SHEET}

\begin{tabular}{|c|c|c|c|c|c|}
\hline To & \multirow{2}{*}{\multicolumn{3}{|c|}{$\begin{array}{l}\text { From } \\
\text { TWRS Functional Baseline } \\
\text { Integration }\end{array}$}} & \multicolumn{2}{|l|}{ Page 1 of 1} \\
\hline Distribution & & & & \multicolumn{2}{|c|}{ Date Sept. 27, 1996} \\
\hline \multirow{2}{*}{\multicolumn{4}{|c|}{ Project Title/Work Order }} & \multicolumn{2}{|c|}{ EDT No. 608747} \\
\hline & & & & \multicolumn{2}{|c|}{ ECN No. $\quad N / A$} \\
\hline Name & MSIN & $\begin{array}{l}\text { Text } \\
\text { With All } \\
\text { Attach. }\end{array}$ & Text Only & $\begin{array}{l}\text { Attach./ } \\
\text { Appendix } \\
\text { Only }\end{array}$ & $\begin{array}{c}\text { EDT/ECN } \\
\text { Only }\end{array}$ \\
\hline
\end{tabular}

In addition to the Signatures/Distributions shown on the cover page of the EDT, the copies of this document are distributed to the following:

\section{REASON FOR TRANSMITTAL}

(REVIEW)

DOE

W. A. Rutherford

A2-45 $\quad X$

ICF Kaiser Hanford Company

J. T. Koberg

G. P. McDonald

G3-12

E6-27

R. L. Fritz

$52-12$

$X$
$X$
$X$

Westinghouse Hanford Company

Paul Felise

R. U. Elwell

K. A. Gasper

R. J. Parazin

L. G. Peck

G. Singh (8 copies)

Bonneville Power Administration

(To be coordinated by W. A. White)

Earl Brown/W.A. White

A2 -45

B4-55

S7-12

G3-21

H5-49

H6-35

H6-11

$x$
$x$
$x$
$x$
$x$
$X$

others

Central Files

DOE Reading Room

A3-88

Al-65

$X$
$X$ 